\title{
Endometriosis: where are we and where are we going?
}

\author{
Alexis D Greene ${ }^{1, *}$, Stephanie A Lang ${ }^{2, *}$, Jessica A Kendziorski², Julie M Sroga-Rios ${ }^{1}$, \\ Thomas J Herzog1,3 and Katherine A Burns ${ }^{2}$ \\ ${ }^{1}$ Department of Obstetrics and Gynecology, University of Cincinnati Center for Reproductive Health, Cincinnati, Ohio, \\ USA, ${ }^{2}$ Department of Environmental Health, University of Cincinnati College of Medicine, Cincinnati, Ohio, USA, and \\ ${ }^{3}$ University of Cincinnati Cancer Institute, University of Cincinnati College of Medicine, Cincinnati, Ohio, USA
}

Correspondence should be addressed to K A Burns; Email: Katherine.Burns@uc.edu

*(A D Greene and S A Lang contributed equally to this work)

\begin{abstract}
Endometriosis currently affects $\sim 5.5$ million reproductive-aged women in the U.S. with symptoms such as painful periods (dysmenorrhea), chronic pelvic pain, pain with intercourse (dyspareunia), and infertility. It is defined as the presence of endometrial tissue outside the uterine cavity and is found predominately attached to sites within the peritoneal cavity. Diagnosis for endometriosis is solely made through surgery as no consistent biomarkers for disease diagnosis exist. There is no cure for endometriosis and treatments only target symptoms and not the underlying mechanism(s) of disease. The nature of individual predisposing factors or inherent defects in the endometrium, immune system, and/or peritoneal cavity of women with endometriosis remains unclear. The literature over the last 5 years (2010-2015) has advanced our critical knowledge related to hormones, hormone receptors, immune dysregulation, hormonal treatments, and the transformation of endometriosis to ovarian cancer. In this review, we cover the aforementioned topics with the goal of providing the reader an overview and related references for further study to highlight the progress made in endometriosis research, while concluding with critical areas of endometriosis research that are urgently needed. Reproduction (2016) 152 R63-R78
\end{abstract}

\section{Introduction}

Endometriosis is an estrogen-dependent gynecological condition characterized by the presence and growth of ectopic endometrial tissue, often associated with inflammation, severe and chronic pain, and infertility (Hickey et al. 2014). Lesions identified during laparoscopy are categorized as superficial peritoneal lesions, endometriomas, or deep infiltrating nodules, with high degree of individual variability in lesion color, size, and morphology. Histopathological analysis requires the presence of at least two features for a diagnosis of endometriosis, the features being endometrial epithelium, endometrial glands, endometrial stroma, and hemosiderin-filled macrophages (Hsu et al. 2010). Retrograde menstruation, in which uterine epithelial and stromal cells are disseminated and implanted into the peritoneal cavity via the fallopian tubes, is the most accepted mechanism for the pathogenesis of endometriosis (Sampson 1927b, Ahn et al. 2015a). More than $90 \%$ of women undergo retrograde menstruation; however, the prevalence of endometriosis in the general population is 6-10\% (Sampson 1927a, Syrop $\&$ Halme 1987). Such a discrepancy between these two values suggests that women who develop endometriosis are likely to have other genetic, biochemical, and pathophysiological factors contributing to development of the disease (Ahn et al. 2015a).

The goal of this review is to provide a broad overview of the advancements in endometriosis research over the last 5 years (2010-2015). First, we delve into animal models often used in endometriosis research. After which, we cover critical areas of endometriosis study, including basic and clinical research, and the transformation of endometriosis into ovarian cancer. Within basic research, we focus on angiogenesis, cytokine/chemokine expression, and hormones and their receptors, and the significance they may play in the pathogenesis of endometriosis. This review is a synopsis of important findings for researchers to quickly find relevant sources of interest to his/her studies.

\section{Animal research models}

The use of animal models in the study of endometriosis allows for the control of numerous variables related to pathogenesis and disease progression, including angiogenesis, inflammation, and hormonal response. Nonhuman primate and rodent models are the most common animal models used, while the chicken chorioallantoic membrane model has limited use. 


\section{Nonhuman primate models}

Nonhuman primates (baboons and rhesus macaques) are often used to study pathogenesis, progression, and treatment of endometriosis. While primates can spontaneously develop endometriosis at a low prevalence (D'hooghe et al. 1996, Zondervan et al. 2004, King et al. 2016), techniques have been developed to increase disease incidence. Cervical occlusion to promote retrograde menstruation (Scott et al. 1953, D'Hooghe et al. 1994) and a homologous model, in which endometrial tissue is excised from a donor primate and surgically transplanted or injected into a recipient primate, are used (Te Linde \& Scott 1950, D'Hooghe et al. 1995, Sillem et al. 1996). Primate models, including advantages and disadvantages, have been described previously (Tirado-Gonzalez et al. 2010, Grummer 2012, King et al. 2016).

\section{Rodent models}

Rodents are often used in endometriosis research due to quick generation time, ability for genetic manipulation, and relatively low cost, especially in comparison to nonhuman primate models. Rodent models of endometriosis are divided into two main groups: heterologous or homologous/autologous models. Heterologous models use human tissue transplanted into immunocompromised mice, while homologous models involve transferring endometrial tissue from one animal to a syngeneic animal (Tirado-Gonzalez et al. 2010, King et al. 2016).

Heterologous models involve the transfer of human endometrial tissue into an immunocompromised rodent, such as athymic nude, severe combined immunodeficient (SCID), or $\operatorname{Rag} 2 \gamma(c)$ mice, to prevent the rodent immune system from attacking the foreign tissue (Zamah et al. 1984, Aoki et al. 1994, Greenberg \& Slayden 2004). Once human tissue is collected, it is disseminated via intraperitoneal or subcutaneous injection into the immunocompromised rodent. Heterologous rodent models with associated advantages and disadvantages have been described (Tirado-Gonzalez et al. 2010, Bruner-Tran et al. 2012, Grummer 2012, King et al. 2016).

Several homologous rodent models are utilized in endometriosis research, and the generation of these models involves several important considerations regarding the reproductive status of the donor and recipient, transplantation method, and potential genetic manipulation (King et al. 2016). Often, the recipient rodents are ovariectomized and treated with estrogens to promote lesion growth (Cummings \& Metcalf 1995, Somigliana et al. 1999, Styer et al. 2008, Burns et al. 2012). Critically valuable for the study of endometriosis is that the homologous model maintains an intact immune system. A large difference between homologous models is the method of transplantation and tissue dissemination. Various models exist for the development of ectopic lesions, including: (1) suturing uterine tissue into the peritoneal wall or intestinal mesentery; (2) injecting minced uterine tissue intraperitoneally to disperse freely and attach at sites within the peritoneal cavity; (3) using entire uterine tissue or endometrial tissue; and (4) using minced "menstruated" tissue for intraperitoneal injection (Vernon \& Wilson 1985, Somigliana et al. 1999, Burns et al. 2012, Greaves et al. 2014). For models used to study endometriosis, it is critically important to remember the definition of and requirements for an endometriotic lesion. Discouragingly, some models inherently do not fulfill these criteria and are suboptimal for the study of endometriosis, ultimately occluding comprehensive comparison and interpretation of data in the scientific literature.

\section{Chicken chorioallantoic membrane model}

The chicken chorioallantoic membrane (CAM) assay is used to study molecular processes involved in adhesion, invasion, and angiogenesis of developing endometriotic lesions. This assay involves culturing human endometrial tissue on the CAM of fertilized chicken embryos (Maas et al. 2001). The CAM has a dense microvasculature, useful for examining angiogenesis and for experimentation with antiangiogenic agents (Nap et al. 2005). This method has been used to study the impact of matrix metalloproteinase (MMP) expression and activity on adhesion and invasion (Nap et al. 2004, Juhasz-Boss et al. 2010). However, it is not suited for studying immunological or inflammatory aspects of lesion development or for potential effects of systemic treatments.

\section{Pathogenesis and progression of endometriosis}

Animal models and human samples are paramount in the study of pathogenesis and progression of endometriosis. They allow for in-depth analysis of factors involved in this disease, including inflammation, angiogenesis, cytokine/chemokine expression, and endocrine alterations such as steroid and steroid receptor expression. These components also form a complex, interacting system greatly impacting the development of endometriosis. While we understand that several other factors are involved in the pathogenesis and progression of this disease, including genetics and epigenetics, and significant advances in these components have been made, covering them in depth is beyond the scope of this review. For researchers interested in these topics, an elegant and comprehensive review by Bulun and coworkers (2015) recently addresses the molecular biology, genetics, and epigenetics of endometriosis and covers 25 years of research (1990-2015). 


\section{Inflammation - angiogenesis}

Angiogenesis is the formation of new blood vessels, and subsequently, is a key process to form functional blood vessels to ectopic menstrual tissue for the establishment/ maintenance of endometriotic lesions. Theorized is that women with endometriosis respond to retrograde menstrual tissue as a "wound" that must be healed and not as "self" that must be removed (Herington et al. 2011). Examining key players involved in angiogenesis, both in women with endometriosis and in animal models, similarities between angiogenesis in endometriotic lesions and angiogenesis in wound healing exist. A variety of growth factors and genes related to angiogenesis have been studied in endometriosis.

The VEGF protein family is well known for roles in angiogenesis, vasculogenesis, and lymphangiogenesis. Human peritoneal fluid (PF) from women with endometriosis show inconsistent protein levels of VEGF, but this may be due to sample size, dilution of PF, or true variability among women. For example, some studies show increased VEGF levels in the PF (Bourlev et al. 2010, Xu et al. 2013, Szubert et al. 2014); however, other studies show no increase in VEGF levels in women with endometriosis compared with healthy women (Barcz et al. 2012, Bersinger et al. 2012, Rathore et al. 2014). Interestingly, more consistency is found in animal models of endometriosis, most likely because of controlled onset of experimental conditions. A variety of rodent models of endometriosis show VEGF levels increase in endometriosis-like lesions (Machado et al. 2010, Ricci et al. 2011, Kumar et al. 2014, Lu et al. 2014a, Machado et al. 2014, Zhao et al. 2015). Data are inconsistent when attempting to target VEGF in the mouse to treat endometriosis (Xu et al. 2011, Novella-Maestre et al. 2012, Virani et al. 2013, Kumar et al. 2014); however, the data suggest that VEGF drives angiogenesis in endometriosis. Furthermore, these results from human and animal models demonstrate challenges of clearly deciphering VEGF as an appropriate marker for endometriosis.

Other angiogenic factors play important roles in the adhesion and maintenance of endometriosis lesions, including hypoxia factors (i.e. HIF1A), MMPs (i.e. MMP9), and microRNAs (miRNA). As mentioned, the peritoneal microenvironment of women with endometriosis is often different from healthy women. In a heterologous mouse model, hypoxic conditions promote angiogenesis and proliferation of endometriosis demonstrated by larger lesions, higher levels of VEGF, HIF1A, Ki67, and PECAM1 (Lu et al. 2014b). Concomitantly, the same group shows that lesion location affects adhesion and angiogenesis when comparing intraperitoneal versus subcutaneous endometriotic tissue injection (Lu et al. 2014a), suggesting that the microenvironment of the peritoneal cavity plays a crucial role in lesion adhesion and angiogenesis. MMPs are proteases required for reorganizing existing blood vessels during budding angiogenesis (Page-McCaw et al. 2007). Recently, the role of MMPs in endometriosis were not studied indepth, but MMPs play a known role in endometriosis (Machado et al. 2010). For example, $\mathrm{Mmp9}^{-/-}$uterine tissue does not grow in a mouse suture endometriosis model (Han et al. 2012); however, this model does not account for actual tissue attachment. An emerging field in endometriosis is the function of miRNA in angiogenesis. Primary eutopic and ectopic endometrial stromal cells exposed to PF from women with endometriosis have downregulated miRNAs known to regulate VEGF expression compared with cells exposed to PF from control women (Braza-Boils et al. 2013, 2014, 2015). Future in-depth analysis of the interplay between inflammation and angiogenesis in the early stages of endometriosis development is needed to determine which molecules could potentially be targeted therapeutically.

\section{Inflammation - cytokine and chemokine expression}

Cytokines and chemokines are emerging as key players in endometriosis pathobiology. Cytokines are a broad group of secreted proteins important in cell signaling, while chemokines are a family of cytokines important in inducing chemotaxis in nearby cells. A complete overview of chemokines and cytokines in endometriosis is too exhaustive; however, these proteins are altered in $\mathrm{PF}$, ectopic lesions, eutopic endometrium, and serum. To demonstrate the growing role of cytokine research in the study of endometriosis, Table 1 lists cytokines and chemokines that appear in more than two endometriosis research papers between 2010 and 2015. Additional to the dysregulation of cytokines/chemokines, altered levels of a large number of cytokines/chemokines are found in cyst fluid removed from endometriomas/chocolate cysts (Chen et al. 2013b). Before elucidating the interplay and implications of chemokines and cytokines in endometriosis, large-scale-controlled human studies or meta-analyses will need to be conducted to fully encompass cytokine dysregulation. Most likely, with the signaling complexity of the immune system and endometriosis as a disease, a single chemokine/cytokine will not diagnose disease, but instead, a disease profile of altered cytokines may be used to establish disease diagnosis. Furthermore, as nicely outlined by Fassbender and coworkers, international standardized methods for BioBanking endometriosis samples needs to be implemented (Fassbender et al. 2013).

\section{Hormones and hormone receptors}

Endometriosis is intimately associated with steroid metabolism and associated pathways, corresponding to the paramount roles estrogen receptors (ESRs) and progesterone receptors (PGRs) play in uterine biology. Both human and animal model studies show endometriosis 
Table 1 Cytokine or chemokine alterations in endometriosis.

\begin{tabular}{|c|c|c|c|}
\hline Cytokine/chemokine & Model & Results & Reference \\
\hline CCL2 (MCP-1) & $\mathrm{hPF}$ &,,++++++ & $\begin{array}{l}\text { (Mier-Cabrera et al. 2011, Margari et al. 2013), (Tao et al. 2011), (Bersinger } \\
\text { et al. 2012) }\end{array}$ \\
\hline \multirow[t]{2}{*}{ CCL5 (RANTES) } & hPF & $N S,+,++$ & $\begin{array}{l}\text { (Bersinger et al. 2012, Margari et al. 2013), (Mier-Cabrera et al. 2011), (Beste } \\
\text { et al. 2014) }\end{array}$ \\
\hline & hEctopic & Qualitative +, ++ & (Wang et al. 2010), (Yang et al. 2013) \\
\hline CCL11 (Eotaxin) & hPF &,+++ & (Bersinger et al. 2012), (Mier-Cabrera et al. 2011) \\
\hline CXCL1 (GROa) & hPF & Nearing & (Bersinger et al. 2012) \\
\hline \multirow[t]{4}{*}{ CXCL8 (IL8) } & hPF & $N S,+,++$ & $\begin{array}{l}\text { (Velasco et al. 2010, Bersinger et al. 2012), (Mier-Cabrera et al. 2011, Beste } \\
\text { et al. 2014), (Milewski et al. 2011, Malhotra et al. 2012) }\end{array}$ \\
\hline & hSerum & ++ & (Carmona et al. 2012) \\
\hline & hEESCs & ++ & (Delbandi et al. 2013) \\
\hline & hPF mRNA Cells & NS & (Yeo et al. 2013) \\
\hline CXCL10 (IP-10) & $\begin{array}{l}\text { hLesion } \\
\text { hPF }\end{array}$ & $\begin{array}{c}\text { NS trend - } \\
++\end{array}$ & $\begin{array}{l}\text { (Bellelis et al. 2013) } \\
\text { (Bersinger et al. 2012) }\end{array}$ \\
\hline \multirow[t]{2}{*}{ CXCL12 (SDF1) } & hEctopic & + & (Bellelis et al. 2013) \\
\hline & hPF & + & (Leconte et al. 2014) \\
\hline \multirow[t]{3}{*}{ IL1B } & hPF &,++++ & (Mier-Cabrera et al. 2011, Beste et al. 2014), (Sikora et al. 2012) \\
\hline & hEctopic & + & (Chen et al. 2013) \\
\hline & hPF cells & NS & (Yeo et al. 2013) \\
\hline IL4 & hPF & NS, ++ & (Mier-Cabrera et al. 2011, Wickiewicz et al. 2013), (Beste et al. 2014) \\
\hline \multirow[t]{4}{*}{ IL6 } & hPF & $\mathrm{NS},+,++,+++$ & $\begin{array}{l}\text { (Rathore et al. 2014), (Mier-Cabrera et al. 2011, Khan et al. 2015), (Velasco } \\
\text { et al. 2010, Kang et al. 2014), (Milewski et al. 2011, Bersinger et al. 2012, } \\
\text { Podgaec et al. 2012, Wickiewicz et al. 2013) }\end{array}$ \\
\hline & hSerum &,,++++++ & (Kinugasa et al. 2011), (Carmona et al. 2012), (Elgafor El Sharkwy 2013) \\
\hline & hEESC & ++ & (Delbandi et al. 2013) \\
\hline & hPF mRNA Cells & NS & (Yeo et al. 2013) \\
\hline \multirow[t]{3}{*}{ IL10 } & hSerum/PF & NS/NS & (Andreoli et al. 2011) \\
\hline & $\mathrm{hPF}$ & $\mathrm{NS},+$ & $\begin{array}{l}\text { (Bersinger et al. 2012, Podgaec et al. 2012), (Mier-Cabrera et al. 2011, } \\
\text { Wickiewicz et al. 2013) }\end{array}$ \\
\hline & hPF mRNA Cells & NS & (Yeo et al. 2013) \\
\hline \multirow[t]{3}{*}{ IL12 } & hSerum/PF & NS/NS & (Andreoli et al. 2011) \\
\hline & hPF & NS & (Mier-Cabrera et al. 2011) \\
\hline & hPF mRNA Cells & NS & (Yeo et al. 2013) \\
\hline \multirow[t]{4}{*}{ IL17A } & hEndo, Serum & $* * /+$ & (Ahn et al. 2015) \\
\hline & hSerum/PF & NS/NS & (Andreoli et al. 2011) \\
\hline & hPF & NS & (Podgaec et al. 2012) \\
\hline & hFF/Serum & $+++/++$ & (Sabbaghi et al. 2014) \\
\hline IL18 & hPF &,+--- & (Bersinger et al. 2012), (Sikora et al. 2012) \\
\hline \multirow[t]{2}{*}{ IL22 } & hEctopic & $* *$ & (Guo et al. 2013) \\
\hline & hSerum & -- & (Santulli et al. 2013) \\
\hline \multirow[t]{2}{*}{ IFNG } & hPF & NS, + & (Wickiewicz et al. 2013), (Mier-Cabrera et al. 2011) \\
\hline & hPF mRNA Cells & NS & (Yeo et al. 2013) \\
\hline \multirow[t]{2}{*}{ MIF } & $\mathrm{hPF}$ & ++ & (Beste et al. 2014) \\
\hline & hEctopic & ++ & (Lin et al. 2010) \\
\hline \multirow[t]{2}{*}{ TGFB } & $\mathrm{hPF}$ & +++ & (Podgaec et al. 2012) \\
\hline & mKO w/human & - size & (Hull et al. 2012) \\
\hline \multirow[t]{5}{*}{ TNFA } & $\mathrm{hPF}$ & $\mathrm{NS},+,++$ & $\begin{array}{l}\text { (Tao et al. 2011, Wickiewicz et al. 2013), (Mier-Cabrera et al. 2011, Beste et al. } \\
\text { 2014, Young et al. 2014a,b), (Khan et al. 2015) }\end{array}$ \\
\hline & hEctopic cd56+ & + & (Chen et al. 2013) \\
\hline & pfNKcell & + & (Funamizu et al. 2014) \\
\hline & bEctopic & NS & (Ilad et al. 2010) \\
\hline & hPF mRNA Cells & NS & (Yeo et al. 2013) \\
\hline
\end{tabular}

Increased levels: $+P<0.05,++P<0.01,+++P<0.001,{ }^{*}$ qualitative IHC. Decreased levels: $-P<0.05$. NS, nonsignificant; h, human; b, baboon; Ectopic, ectopic endometriosis lesion; PF, peritoneal fluid; FF, follicular fluid; EESC, ectopic endometrial stromal cells.

is estrogen (E2) dependent and is regulated through the ERs alpha and beta (ESR1 and ESR2) (Burns et al. 2012, Pellegrini et al. 2012, Wu et al. 2012, Han et al. 2015, Zhao et al. 2015). An increased ratio of ESR2 to ESR1 mRNA is observed in endometriomas compared with endometriosis implants and eutopic endometrium (Bukulmez et al. 2008). Knockout studies in mice show that lesion attachment, size, and proliferation are closely associated with the presence or absence of Esr 1 and Esr2
(Burns et al. 2012). The Bulun Laboratory has focused efforts on ESR2 and demonstrates that ESR2 expression is highly increased in endometriotic tissue due to hypomethylation of the promoter region (Dyson et al. 2014). They also identify RAS-like estrogen-regulated growth inhibitor (RERG) as a key enzymatic target of estradiol signaling through ESR2. This enzyme regulates numerous factors involved in the progression of endometriosis, including cell proliferation and apoptotic resistance 
(Monsivais et al. 2014). Additionally, they have nicely detailed multiple studies on the role of ESR2 in endometriosis in a comprehensive review (Bulun et al. 2012). Use of estrogen receptor ligands, inhibitors, and agonists also support the role of ESRs in endometriosis (Colette et al. 2011, Kulak et al. 2011, Han et al. 2012, Chen et al. 2014, Naqvi et al. 2014, Zhao et al. 2015, Palmer et al. 2016). Specifically, selective estrogen receptor modulators (SERMs) are synthetic molecules which bind to ESRs and act as either antagonists or agonists. Two compounds, chloroindazole (CLI) and oxabicycloheptene sulfonate (OBHS), have strong ERdependent anti-inflammatory effects on endometriosis lesions in vivo in a suture mouse model of endometriosis and in vitro, with primary human endometriotic stromal cells (Zhao et al. 2015). Their data suggest that both CLI and OBHS inhibit the establishment of new lesions and reduce the size of already established lesions; however, important next studies using these inhibitors will be to examine lesion attachment without a suture endometriosis model, as suturing alone creates an unnecessary inflammatory response similar to any reaction toward a foreign body (Carr et al. 2009) and, in some respects, negates the use of homologous tissue.

Progesterone (P4) and its receptor isoforms, PGR-A and $-\mathrm{B}$, also have established roles in endometriosis. The endometrium of women with endometriosis demonstrates an attenuated response to P4 because PGRresponsive genes are not suppressed in the eutopic endometrium of women with endometriosis compared with healthy women in the early secretory phase of the menstrual cycle, suggesting the presence of a progesterone resistance phenotype in these women (Burney et al. 2007). A more recent study to discriminate between the PGR isoforms finds elevated levels of PGR-A in endometriosis lesions and eutopic endometrium from women with endometriosis and shows a PGR-A-dominant state, regardless of menstrual phase (Bedaiwy et al. 2015). While the data are from a small cohort of women, their findings suggest that a PGR-A-dominant menstrual efflux in the peritoneal cavity may mirror the growth and invasive properties known about cancers overexpressing PGR-A.

Aromatase is the enzyme responsible for the aromatization of androgens into estrogens. Aromatase protein level is increased in vaginal septum lesions and decreased in intestinal lesions in women with endometriosis (Goncalves et al. 2015). Ovarian endometriomas express higher levels of aromatase and peroxisome proliferator-activated receptor gamma coactivator 1 alpha (PPARGC1A) than associated ectopic lesions and eutopic endometrium (Suganuma et al. 2014). Activation of peroxisome proliferator-activated receptor gamma (PPARG) inhibits the growth and survival of human endometriotic cells by suppressing E2 biosynthesis and prostaglandin E2 (PGE2) signaling (Lebovic et al. 2013). The use of Als for the treatment of endometriosis is becoming more common and is discussed below.

The last 5 years have expanded our knowledge of hormones, hormone receptors (HRs), and associated coregulators. These studies are important for integrating dysregulation found in ectopic lesions, but also have allowed for the design of more targeted areas to be studied. More in-depth studies with targeted HR uterine knockouts, coregulator knockouts, and/or with the recently synthesized SERMS will lead to greater understanding of the role of HR in disease. The results of these future experiments will allow for even more targeted experiments and hopefully development and use of more targeted therapeutic paradigms.

\section{Interactions between inflammation and the endocrine system}

Crosstalk between the immune/inflammatory and endocrine systems can significantly impact pathogenesis and progression of endometriosis. The sex hormone receptors can markedly alter the immune response in ectopic tissue. Both ESR1 and ESR2 have distinct roles in regulating the immune response, as discovered through the use of multiple animal models. Signaling of E2 through ESR1 appears to have both an anti- and pro-inflammatory roles, as observed by increased mitogenesis and decreased IFNG, TNF, and IL12 transcript expression (Burns et al. 2012). Overexpression of ESR2 activates the inflammasome and modulates TNF-induced apoptosis, as observed with increases in IL1B and cleaved caspase-1 levels and decreases in cleaved caspase-8 levels in ectopic lesions (Han et al. 2015).

Hormones themselves also directly alter the immune system. Monocyte chemotactic factor-1 (MCP1/CCL2) is an example of a chemokine significantly affected by sex hormones. In human endometrial endothelial cells from women with endometriosis, both E2 and P4 increase MCP1 mRNA and protein expression; this effect is not observed in cells from healthy women (Luk et al. 2010). After treating monocytes with control peritoneal fluid (cPF) or endometriotic peritoneal fluid (ePF), the addition of E2 to the culture suppresses MCP1 release from CPF-treated monocytes. However, E2 does not suppress MCP1 release from ePF-treated monocytes (Lee et al. 2012). E2 promotes a pro-inflammatory environment by increasing the secretion of IL6 and TNF from peritoneal macrophages from women with endometriosis compared with control women. This effect is further enhanced by co-treatment with lipopolysaccharide (Khan et al. 2015). Other chemokines, CXCR4 and CXCL12, are downregulated by sex hormones in human epithelial endometrial cells and human endometrial stromal cells, respectively (Ruiz et al. 2010). All of these findings provide evidence that the immune environment and its response to sex hormones is altered in women 
with endometriosis; however, a definitive mechanism for these differences is largely unknown and is a major area that future research needs to address.

A third aspect to the endocrine-immune crosstalk involves aromatase expression. Macrophage migration inhibitory factor (MIF) increases aromatase mRNA and protein expression in ectopic endometrial stromal cells via post-transcriptional stabilization (Veillat et al. 2012). Interestingly though, E2 treatment in the same cells increases MIF mRNA and protein expression, suggesting a positive feedback loop between the endocrine and immune systems in women with endometriosis (Veillat et al. 2012). Potential for a continuous positive-feedback loop between these systems is an area for further exploration to understand the dynamic and altered environment in women with endometriosis.

\section{Clinical symptoms and diagnosis of endometriosis}

Endometriosis is often characterized by pelvic pain that manifests in a variety of ways; most commonly, patients present with dysmenorrhea, noncyclical pelvic pain, and dyspareunia, but other common symptoms are dyschezia, dysuria, and infertility (Fritz MA 2011, Practice Committee of the American Society for Reproductive 2014). Definitive diagnosis of endometriosis is by visualization or excision of lesions via laparoscopy. The American Society for Reproductive Medicine (ASRM) grading system for endometriosis guides surgeons in determining the severity of disease (American Society for Reproductive Medicine 1997) and was created to help predict pregnancy with fertility treatment. The grading system does not correlate with pain level, and has limited reproducibility to predict pregnancy; however; it remains the best objective to communicate disease severity between physicians and surgeons.

Accuracy of visual diagnosis increases with disease severity (Fernando et al. 2013). While the European Society of Human Reproduction and Embryology (ESHRE) requirements suggest that surgical diagnosis by visualization alone is appropriate, ASRM stresses that biopsies be taken when diagnosis is unclear (Fernando et al. 2013). Importantly, poor correlation exists between clinical symptoms and disease burden (Dunselman et al. 2014, Practice Committee of the American Society for Reproductive 2014). Diagnosing endometriosis by pelvic pain alone is not sufficient, as pelvic pain is also a symptom of many other diseases, including pelvic adhesions, adenomyosis, and gastrointestinal urologic disorders (Bulun 2009, Practice Committee of the American Society for Reproductive 2014). This vast differential diagnosis for pelvic pain can complicate the diagnosis of endometriosis.

\section{Treatments}

Several different treatment modalities, including medical, surgical, and alternative, exist for endometriosis. First-line medical management includes options that have a favorable safety and cost profile, that are well tolerated by the patient, and that are effective in treatment (Zito et al. 2014). If medical therapy fails, surgical therapy to remove endometriotic lesions and endometriomas is performed. Finally, alternative therapies are being used to supplement conventional treatments.

\section{Medical therapy}

Combined oral contraceptive pills (OCPs), which include ethinyl estradiol (EE) and various progestins, are used to treat endometriosis, particularly in women not trying to conceive (Practice Committee of the American Society for Reproductive 2014, Zito et al. 2014). Historically, OCPs have been first-line therapy, but most studies are decades old and the pills contained higher doses of EE. Based on a more recent randomized control trial (RCT) in 100 patients, low-dose OCPs decrease pain more significantly than placebo on the Visual Analog Scale (VAS) (Harada et al. 2008). Continuous OCPs decrease recurrence rates of dysmenorrhea after surgical therapy when compared with cyclic OCPs (Zorbas et al. 2015, Muzii et al. 2016). Of the progestins, the 19-nortestosterone derivatives are less androgenic and offer better side-effect profiles (Angioni et al. 2014). In an RCT, dienogest significantly decreases endometriosis-related pain similar to gonadotropinreleasing hormone agonists $(\mathrm{GnRHa})$, both as initial and postoperative therapy, without the negative sideeffect profile of GnRHa (Angioni et al. 2014, Andres Mde et al. 2015, Granese et al. 2015, Strowitzki et al. 2015). Levonorgestrel, delivered through an intrauterine system after conservative surgery, significantly decreases dysmenorrhea, dyspareunia, and noncyclic pelvic pain compared with expectant management in an RCT of 55 patients (Tanmahasamut et al. 2012, Imai et al. 2014).

Several therapies aim to create a hypoestrogenic state in women with endometriosis. Examples of these treatments include $\mathrm{GnRHa}, \mathrm{GnRH}$ antagonists (GnRH-ant), synthetic androgens, and Als. GnRHa therapy downregulates gonadotropin receptors and desensitizes the body to gonadotropins. It decreases pain and endometriotic nodules in comparison to placebo (Leone Roberti Maggiore et al. 2014, Brown \& Farquhar 2015). A multicenter RCT comparing GnRHa to OCPs as postsurgical therapy reports that both groups increase quality of life scores (Granese et al. 2015). Although GnRHa is proven effective, a severe side effect is decreased bone mineral density (BMD); therefore, estrogens or progestins are given for bone protection (Leone Roberti Maggiore et al. 2014, Zito et al. 2014). In contrast, GnRH-ant inhibits gonadotropin receptors. 
Elagolix improves dysmenorrhea and dyspareunia compared with placebo in a phase 2 RCT (Ezzati \& Carr 2015, Munoz-Hernando et al. 2015), and comparing BMD profiles of elagolix with depot medroxyprogesterone acetate, both minimally impact BMD (Carr et al. 2014, Ezzati \& Carr 2015).

Danazol, a synthetic androgen, inhibits the luteinizing hormone (LH) surge; however, it also increases free testosterone, causing undesired side effects including hirsutism, deepening of voice, weightgain, and acne. Danazol effectively decreases pelvic pain compared with placebo, and is as effective as other hormonal therapies, but the numerous side effects limit the use (Practice Committee of the American Society for Reproductive 2014, Zito et al. 2014). Als are currently a second-line treatment in women refractory to first-line treatments (Abu Hashim 2014). Als such as letrozole decrease estrogen stimulation of endometriosis and, when used in combination with $\mathrm{GnRHa}$, improve pelvic pain more than GnRHa alone. Additionally, letrozole with norethindrone acetate add-back has improved endometriosis symptoms, and high dose aromatase inhibition reduces ovarian endometrioma size (Agarwal et al. 2015). In contrast, a small RCT investigating postsurgical endometriosis pain comparing OCPs alone and in combination with letrozole reports similar pain scores, suggesting no benefit with letrozole addition (Almassinokiani et al. 2014).

\section{Surgical therapy}

Surgical therapy for endometriosis is typically necessary for intractable pelvic pain despite medical therapy. Several different surgical techniques are performed (Table 2), including excision/removal of endometriosis, uterosacral nerve ablation, presacral neurectomy, and hysterectomy with bilateral salpingo-oophorectomy (BSO) (Daniels et al. 2010, Healey et al. 2014, Posadzka et al. 2015), and some techniques provide better symptomatic control than others. For symptom improvement and preventing disease recurrence, endometrioma removal is superior to drainage (Duffy et al. 2014, Practice Committee of the American Society for Reproductive 2014). Hysterectomy without BSO is less effective because of continued hormonal stimulation of microscopic endometriotic lesions. Hysterectomy with BSO leads to surgical menopause, which negatively impacts bone and cardiac health. Extreme surgical management is reserved for patients who fail conservative management (Duffy et al. 2014, Practice Committee of the American Society for Reproductive 2014).

\section{Alternative therapy}

Given that endometriosis is such a difficult disease to treat, alternative therapies are welcomed in addition to conventional therapy. Comparing Chinese medicine (CM) to GnRHa as postsurgical treatment for endometriosis found no differences in recurrence rates on

Table 2 Endometriosis surgical treatments and associated efficacy.

\begin{tabular}{|c|c|c|c|}
\hline Surgical treatment & Surgical technique & Compared treatment & Efficacy \\
\hline Laparoscopic ablation & Ablate, or apply heat, to lesion & $\begin{array}{l}\mathrm{CO}_{2} \text { laser vs electric } \\
\text { cautery } \\
\text { Diagnostic laparoscopy }\end{array}$ & $\begin{array}{l}\text { Decreased pain with ablation (NRS 3) vs } \mathrm{CO}_{2} \\
\text { laser (NRS) (Posadzka et al. 2015) } \\
\text { Decreased overall pain OR } 5.63 \text { (Duffy et al. } \\
\text { 2014) }\end{array}$ \\
\hline Laparoscopic excision & Remove lesion with scissor or laser & Ablation & $\begin{array}{l}\text { No difference in overall pain, dyspareunia, or } \\
\text { dyschezia at } 1 \text { year (Bulun 2009, Duffy et al. } \\
\text { 2014) } \\
\text { Excision decreased dyspareunia (VAS 3.2) vs } \\
\text { ablation (VAS 6.0) at } 5 \text { years (Healey et al. } \\
\text { 2014) } \\
\text { Ablation required more medical treatment (31\%) } \\
\text { vs excision (20\%) (Healey et al. } 2014 \text { ) }\end{array}$ \\
\hline Conservative laparoscopy & $\begin{array}{l}\text { Ablate or excise lesions, restore } \\
\text { anatomy, adhesiolysis }\end{array}$ & Diagnostic laparoscopy & $\begin{array}{l}\text { Decreased overall pain OR } 6.58 \text { (Duffy et al. } \\
\text { 2014) }\end{array}$ \\
\hline $\begin{array}{l}\text { Laparoscopic uterosacral } \\
\text { nerve ablation }\end{array}$ & $\begin{array}{l}\text { Ablate nerve fibers responsible for } \\
\text { pain pathway }\end{array}$ & Conservative laparoscopy & No difference in pain level (Daniels et al. 2010) \\
\hline Endometrioma removal & $\begin{array}{l}\text { Separate cyst wall from ovary and } \\
\text { excise cyst }\end{array}$ & Cyst drainage & $\begin{array}{l}\text { Decreased recurrence of cyst (Dunselman et al. } \\
\text { 2014) } \\
\text { Decreased recurrence of dysmenorrhea (OR 0.15) } \\
\text { (Brown \& Farquhar 2015) }\end{array}$ \\
\hline Presacral neurectomy & $\begin{array}{l}\text { Disrupts sympathetic innervation of } \\
\text { uterus at level of superior } \\
\text { hypogastric plexus }\end{array}$ & Conservative laparoscopy & $\begin{array}{l}1 \text { RCT: decrease midline dysmenorrhea (Practice } \\
\text { Committee of the American Society for } \\
\text { Reproductive 2014) (Dunselman et al. 2014) } \\
1 \text { RCT: no additional benefit (Practice Committee } \\
\text { of the American Society for Reproductive 2014) }\end{array}$ \\
\hline Hysterectomy+BSO & $\begin{array}{l}\text { Debulking to place in surgical } \\
\text { menopause }\end{array}$ & Hysterectomy without BSO & $\begin{array}{l}\text { Improved symptoms (Practice Committee of the } \\
\text { American Society for Reproductive 2014) } \\
\text { (Dunselman et al. 2014) (Duffy et al. 2014) }\end{array}$ \\
\hline
\end{tabular}

BSO, bilateral salpingo-oophorectomy; VAS, visual analog scale; NRS, numeric rating scale; OR, odds ratio. 
follow-up (Weng et al. 2015). In contrast, Chinese herbal enemas decrease dysmenorrhea comparable to danazol (Kong et al. 2014), and CM and herbal enema combination is superior to danazol in decreasing pain symptoms (Flower et al. 2012). An acupuncture study in addition to conventional medical therapy significantly decreases pelvic pain by $5-6$ points on the 10-point VAS (Rubi-Klein et al. 2010). Pelvic physical therapy includes internal manual treatment to stretch pelvic floor muscles, myofascial release, biofeedback, and trigger point release. In those with myofascial chronic pelvic pain, $63 \%$ report significant pain improvement after at least 6 sessions (Bedaiwy et al. 2013). Exercise can provide pain relief, based on questionnaire studies composed of 50-2730 women with endometriosis and 400-4000 control women; however, other survey studies correlate exercise with increased pelvic pain. Unfortunately, not all of these studies are controlled and all are from self-reporting (Bonocher et al. 2014). Large prospective cohort or case-control studies demonstrate increased risk of endometriosis with diets high in trans-fatty acids and decreased risk with diets containing high levels of long-chain omega 3 fatty acids (Hansen \& Knudsen 2013). More high quality studies are needed in these areas, and importantly, a positive publication selection bias likely exists with alternative therapies, exaggerating true effectiveness (Kong et al. 2014).

\section{Association between endometriosis and cancer}

The potential association between endometriosis and cancer has been theorized for decades. This association is based upon observational case-control and cohort studies that propose malignant transformation occurs within endometriotic lesions, giving rise to cancer. Our moleculargenetic understanding of both endometriosis and ovarian cancer continues to rapidly evolve; yet, a definitive mechanism for malignant transformation remains elusive.

\section{Risk and prognosis}

The $10 \%$ prevalence of endometriosis, and an even higher prevalence for women with infertility or chronic pelvic pain, makes the establishment of an absolute "cause-and-effect" relationship problematic. Lifetime risk of developing ovarian cancer in the general population is $\sim 1.4 \%$, with a median age of onset in the early 60s (Schorge et al. 2010). Epithelial ovarian cancer is no longer seen as a single disease, but rather a constellation of multiple diseases based upon histologic subtypes and unique molecular signatures (Galic et al. 2013). The risk of ovarian cancer increases for women who incur fewer pregnancies and/or suffer from infertility. The possibility of confounding when assessing associative risk between these two entities must be considered because infertility is related to both conditions.

Nonetheless, a number of epidemiologic and clinical features lead investigators to propose an association between endometriosis and cancer. The establishment of an association was reported 90 years ago (Sampson 1925) and was refined in 1953, proposing that benign endometriosis should be observed in close anatomic proximity to the arising endometriosis-associated cancer (Scott 1953). Chief among the observations are that both entities produce tissues that can metastasize, invade, and destroy normal surrounding tissues. Furthermore, cancers often are identified in endometriotic lesions or in tissues that are contiguous with endometriosis, and there are often findings of candidate precursor lesions exhibiting histologic atypia in these surrounding tissues (Wei et al. 2011). Finally, endometriosis in younger women, which persists into older age, creates a long window for malignant transformation.

Several retrospective studies initially document the increased rate of endometriosis in women with ovarian cancer. A Swedish study containing over 20,000 patients that cross-matched inpatient endometriosis diagnosis and any cancer diagnosis (Brinton et al. 1997) found a small increased risk of any cancer, but the risks were not confirmed upon long-term follow-up (Brinton et al. 1997). The risk of ovarian cancer, however, is significantly increased in both the initial and longterm analyses. In patients with a history of prolonged endometriosis, the statistical risk for the development of ovarian cancer is even higher.

A linkage analysis of over 99,000 women from Denmark shows that an endometriosis-related increase

Table 3 Summary of risks associated with endometriosis and cancer from registry studies by Brinton et al. (1997, 2005).

\begin{tabular}{|c|c|c|c|}
\hline Population & Risk & SIR* or RR & $95 \% \mathrm{Cl}$ \\
\hline History of endometriosis admission (HEA) & Any cancer & $1.2^{*}$ & $1.1-1.3 *$ \\
\hline HEA & Ovarian cancer & $1.9^{*}$ & $1.3-2.8^{*}$ \\
\hline HEA \& prolonged endometriosis & Ovarian cancer & $4.2^{*}$ & $2.0-7.7 *$ \\
\hline HEA & Endometrial cancer & $1.1^{*}$ & $0.6-1.9 *$ \\
\hline HEA long-term F/U & Any cancer & & \\
\hline HEA long-term F/U & Ovarian cancer & $1.43^{*}$ & $1.19-1.71 *$ \\
\hline Long-term F/U \& prolonged endometriosis & Ovarian cancer & $2.23 *$ & $1.36-3.44^{*}$ \\
\hline HEA Denmark cohort & Clear cell ovarian cancer & 3.37 & $1.24-9.14$ \\
\hline HEA Denmark cohort & Endometrioid ovarian cancer & 2.53 & $1.19-5.38$ \\
\hline
\end{tabular}

HEA, history of endometriosis admission; SIR, standardized incidence ratio; RR, relative risk; Cl, confidence interval; F/U, follow-up. *denotes SIR. 
in ovarian cancer occurs in two histologic subtypes, clear cell and endometrioid (summarized in Table 3) (Brinton et al. 2005). Recent evidence also suggests a correlation between endometriosis and high-grade serous histologic type ovarian cancer (Lee et al. 2016). A large case-control study confirms an approximate threefold increased risk of clear cell or endometrioid ovarian cancer in association with endometriosis (Rossing et al. 2008). Malignant transformation risk to ovarian cancer from ovarian endometriosis is reportedly $0.2-2.5 \%$ (Gadducci et al. 2014). Recent studies also show the association between endometriosis and different forms of ovarian cancer: serous, mucinous, clear cell, and endometrioid, with the predominant cell types being clear cell and endometrioid (Table 4).

A meta-analysis conducted by Kim et al. (2014) evaluates the risk and prognosis of ovarian cancer in $\sim 445,000$ women with or without endometriosis. Based on 35 studies, women with endometriosis are significantly at risk of developing ovarian cancer; however, stage is more likely to be early and low-grade, suggesting that the cancer is slow growing and less invasive. Endometrioid and clear cell are common in women with endometriosis, with the serous subtype occurring less frequently and the mucinous subtype displaying no differences between control women and women with endometriosis (Kim et al. 2014). Endometriosis does not affect prognosis, and the overall survival in women with endometriosis-associated ovarian cancer (EAOC) and in women with non-EAOC are similar when accounting for histology, disease status, assessment of endometriosis, and potential confounding factors. Unfortunately, the effect of endometriosis on a successful debulking surgery is not analyzed (Kim et al. 2014), so it is unknown if there is a benefit in survival in women with EAOC.

\section{Proposed mechanisms of malignant transformation}

Complex hormonal, genetic, and immunologic interactions must be considered when assessing the interplay

Table 4 Ovarian cancer types arising from endometriosis transformation.

\begin{tabular}{|c|c|c|c|}
\hline Population (\# patients EAOC/total in study) & Ovarian cancer type in EAOC & Age (mean \pm S.D.) years & Reference \\
\hline Quebec, BC (41/2854) & $\begin{array}{l}\text { Serous } 19.51 \% \\
\text { Mucinous NR } \\
\text { Clear cell } 21.9 \% \\
\text { Endometrioid } 24.4 \%\end{array}$ & $\begin{array}{l}\text { OC } 53.9 \pm 11.4 \\
\text { EAOC } 48.3 \pm 10.8\end{array}$ & (Aris 2010) \\
\hline Belegrade, Serbia (23/210) & $\begin{array}{l}\text { Serous } 3.5 \% \\
\text { Mucinous NR } \\
\text { Clear cell } 36.8 \% \\
\text { Endometrioid } 31.6 \%\end{array}$ & NR & (Dzatic-Smiljkovic et al. 2011) \\
\hline Michigan, USA (42/184) & $\begin{array}{l}\text { Serous } 55 \% \\
\text { Mucinous } 10 \% \\
\text { Clear cell } 21 \% \\
\text { Endometrioid } 14 \%\end{array}$ & $\begin{array}{l}\text { OC } 59 \\
\text { EAOC } 52\end{array}$ & (Kumar et al. 2011) \\
\hline Athens, Greece (17) & $\begin{array}{l}\text { Serous } 5.9 \% \\
\text { Mucinous NR } \\
\text { Clear cell } 58.8 \% \\
\text { Endometrioid } 35.3 \%\end{array}$ & EAOC $58(27-76)$ & (Kondi-Pafiti et al. 2012) \\
\hline $\begin{array}{l}\text { Ovarian Cancer Association Consortium } \\
(738 / 7911)\end{array}$ & $\begin{array}{l}\text { Serous } 7.1 \% \\
\text { Mucinous } 6.0 \% \\
\text { Clear cell } 20.2 \% \\
\text { Endometrioid } 13.9 \%\end{array}$ & OC 56.1 & (Pearce et al. 2012) \\
\hline Ankara, Turkey (45/1086) & $\begin{array}{l}\text { Serous } 13.3 \% \\
\text { Mucinous } 8.9 \% \\
\text { Clear cell } 37.8 \% \\
\text { Endometrioid } 33.3 \%\end{array}$ & $\begin{array}{l}\text { EAOC } 56.3 \\
\text { EAOC } 55(35-77)\end{array}$ & (Boyraz et al. 2013) \\
\hline Massachusetts, USA (67/134) & $\begin{array}{l}\text { Serous } 0 \% \\
\text { Mucinous NR } \\
\text { Clear cell } 38.8 \% \\
\text { Endometrioid } 61.2 \%\end{array}$ & $\begin{array}{l}\text { OC } 56.6 \\
\text { EAOC } 51.7\end{array}$ & (Davis et al. 2014) \\
\hline Milano, Italy (27/73) & $\begin{array}{l}\text { Serous NR } \\
\text { Mucinous NR } \\
\text { Clear cell } 76.1 \% \\
\text { Endometrioid NR }\end{array}$ & $\begin{array}{l}\text { OC } 58.4 \pm 11.2 \\
\text { EAOC } 51.4 \pm 10\end{array}$ & (Scarfone et al. 2014) \\
\hline San Juan, Puerto Rico (20/192) & $\begin{array}{l}\text { Serous } 2.2 \% \\
\text { Mucinous } 2.7 \% \\
\text { Clear cell } 23 \% \\
\text { Endometrioid } 50 \%\end{array}$ & $\begin{array}{l}\text { OC } 56.1 \pm 14.9 \\
\text { EAOC } 48.8 \pm 11.6\end{array}$ & (Acien et al. 2015) \\
\hline Shiraz, Iran $(28 / 110)$ & $\begin{array}{l}\text { Serous } 14.5 \% \\
\text { Mucinous } 0 \% \\
\text { Clear cell } 14.5 \% \\
\text { Endometrioid } 39 \%\end{array}$ & $\begin{array}{l}\text { OC } 50.18 \pm 12.8 \\
\text { EAOC } 49.93 \pm 9.36\end{array}$ & (Akbarzadeh-Jahromi et al. 2015) \\
\hline
\end{tabular}

OC, ovarian cancer; EAOC, endometriosis-associated ovarian cancer; NR, not reported. 
between endometriosis in the development of epithelial primary peritoneal or ovarian carcinomas. Chronic inflammation, autocrine and paracrine effects, hormonal interactions, and microenvironmental alterations caused by endometriosis in the pelvic region could be relevant mechanisms for malignant transformation. Aberrant immune function, stimulated by estrogens, may create a positive-feedforward loop, enhancing growth and invasiveness of endometriosis and promoting malignant transformation (Ness 2003). Zanetta and coworkers report a role for a hyper-estrogenic state in stimulating endometriosis and promoting malignant transformation (Zanetta et al. 2000).

A permissive microenvironment and accumulation of genetic mutations is suggested to cause malignant change in endometriosis (Wei et al. 2011). Distinct molecular events may occur in early stages of tumorigenesis of endometriosis-associated carcinoma. Recent studies focus on genetic alterations such as phosphatase and tensin homolog (PTEN), tumor protein p53 (TP53), and B-cell lymphoma $(B C L)$ gene mutations that lead to malignant changes in endometriosis (Nezhat et al. 2008, Munksgaard \& Blaakaer 2012, Lai et al. 2013, McConechy et al. 2014). An interplay of genetics and oxidative stress, with decreased expression of interleukin 1 receptor type 2 (ILIR2), is a common signature between endometrioid ovarian cancer and endometriosis (Kobayashi et al. 2009, Keita et al. 2010, 2011). IL1 ligands are expressed by all endometriosis-associated ovarian cancer subtypes and endometrial cells. A decrease in IL1R1 levels, a protector against the tumorigenic effects of IL1, occurs in endometrioid carcinoma (Keita et al. 2010, 2011).

Multiple tumor-associated somatic mutations, detected by examining single gene or by whole genome sequencing, have revealed a signature of mutations. Mutations in catenin beta 1 (CTNNB1) are seen in 60\% of ovarian endometrioid carcinomas (Matsumoto et al. 2015). Mutations in AT-Rich Interactive Domain $1 \mathrm{~A}$ (ARID1A) and phosphatidylinositol-4,5-bisphosphate 3-kinase, catalytic subunit alpha (PIK3CA) appear most consistently in clear cell ovarian carcinomas (Gadducci et al. 2014, Anglesio et al. 2015, Matsumoto et al. 2015). Mutations in ARID1A, involved in chromatin remodeling, are present in both clear cell (15-75\%) and endometrioid carcinomas (30-55\%) (Wiegand et al. 2010, Gadducci et al. 2014). Associated with malignant transformation, mutations in ARID1A lead to the loss of its product, BAF250a, which correlates strongly with ovarian clearcell carcinoma and endometrioid carcinoma subtypes, as well as with high-grade endometrial carcinomas (Wiegand et al. 2010, 2011, Ayhan et al. 2012, Lowery et al. 2012, Samartzis et al. 2012, Chene et al. 2015). ARID1A mutations and BAF250a loss are also observed in tumors and contiguous atypical endometriosis, but not in distant endometriotic lesions. The loss of ARID1A expression usually coexists with PI3K-Akt pathway activation and/or zinc finger protein 217 (ZNF217) amplification in ovarian clear cell cancers and may indicate an early event in the malignant transformation of endometriosis into the various histotypes of ovarian cancer (Ayhan et al. 2012, Huang et al. 2014).

Loss of PTEN is observed in clear cell-associated endometriosis and cancers, including a significant increase in expression levels of $\mathrm{X}$-ray repair crosscomplementing protein 5 (XRCC5), patched 2 ( $\mathrm{PTCH} 2)$, elongation factor 1-alpha 2 (EEF1A2), and protein phosphatase 1 regulatory subunit 14B (PPP1R14B). However, these changes are not observed in benign endometriosis (Worley et al. 2015). PTEN loss is proposed as an early and permissive event in endometriosis development, while loss of ESR1 and polycombmediated transcriptional factor cause ultimate malignant transformation (Worley et al. 2015).

Future research will clarify the likely complex interaction among genetic alterations, estrogen exposure, inflammatory cytokines, and the immunologic microenvironment in the transformation of endometriosis to endometrioid and clear cell ovarian and primary peritoneal cancers. Treatment of these cancers will hopefully improve with the use of targeted and immunologic therapies that address the underlying causes of malignant transformation.

\section{Concluding remarks: where are we going?}

While the studies reviewed from the last 5 years demonstrate a deeper understanding of endometriosis as dysregulations pertain to hormones, hormone receptors, immune function, and transformation to ovarian cancer, endometriosis still remains mysterious from many facets. Critically needed for this enigmatic disease are mechanistic understandings of disease initiation and perturbation that will hopefully lead to the development of noninvasive disease diagnosis and the development of treatments that do not negate hormonal cyclicity or have other undesired side-effect profiles and decrease the need for surgical extirpation. To allow for this to happen, the following areas of need are identified:

- Establish clear limits to animal models and clarify what the model may and may not reveal.

- Establish international standards for collection of patient information and samples as outlined by (Fassbender et al. 2013).

- Establish disease profile through clearer understanding of cytokines and the potential association with autoimmune disorders.

- Characterization of interplay between the hormonal milieu and immune system.

- Focus on lifetime exposures, acute and chronic, to endocrine disrupting chemicals that may interfere with uterine development, immune system regulation, and ultimately endometriosis development. 
- Full recognition that this disease is truly multifaceted with pain, psychology, infertility, immunity, etc.

- Transformation of endometriosis to ovarian cancer through characterization of the lag between endometriosis found on the ovary to an ovarian cancer diagnosis.

- Determine if age, parity, weight, and hormonal regulators (oral contraceptives) contribute to transformation to cancer diagnosis.

\section{Declaration of Interest}

A D G, S A L, J A K, J M S-R, and K A B do not have any conflict of interests to disclose. $\mathrm{T} \mathrm{J} \mathrm{H}$, in the last 2 years, has served on Advisory boards to: Roche/Genentech, AstraZeneca, Caris Life Sciences, Clovis Oncology, and Johnson \& Johnson.

\section{Funding}

Funding for this research was provided in part by NIEHS grant 4R00ES021737-02 and Startup Funds from the University of Cincinnati College of Medicine to K A B.

\section{References}

Abu Hashim H 2014 Potential role of aromatase inhibitors in the treatment of endometriosis. International Journal of Womens Health 6 671-680. (doi:10.2147/IJWH)

Acien P, Velasco I, Acien M, Capello C \& Vela P 2015 Epithelial ovarian cancers and endometriosis. Gynecologic and Obstetric Investigation 79 126-135. (doi:10.1159/issn.0378-7346)

Agarwal S, Fraser MA, Chen I \& Singh SS 2015 Dienogest for the treatment of deep endometriosis: case report and literature review. Journal of Obstetrics and Gynaecology Research 41 309-313. (doi:10.1111/jog.12527)

Ahn S, Monsanto S, Miller C, Singh S, Thomas R \& Tayade C 2015a Pathophysiology and immune dysfunction in endometriosis. BioMed Research International 2015 795976. (doi:10.1155/2015/795976)

Ahn SH, Edwards AK, Singh SS, Young SL, Lessey BA \& Tayade C 2015b IL-17A Contributes to the pathogenesis of endometriosis by triggering proinflammatory cytokines and angiogenic growth factors. Journal of Immunology 195 2591-2600. (doi:10.4049/jimmunol.1501138)

Akbarzadeh-Jahromi M, Shekarkhar G, Sari Aslani F, Azarpira N, Heidari Esfahani M \& Momtahan M 2015 Prevalence of endometriosis in malignant epithelial ovarian tumor. Archieves of Iranian Medicine 18 844-848.

Almassinokiani F, Almasi A, Akbari P \& Saberifard M 2014 Effect of Letrozole on endometriosis-related pelvic pain. Medical Journal of the Islamic Republic of Iran $\mathbf{2 8} 107$.

American Society for Reproductive Medicine 1997 Revised American Society for Reproductive Medicine classification of endometriosis: 1996. Fertility and Sterility 67 817-821. (doi:10.1016/S0015-0282(97)81391-X)

Andreoli CG, Genro VK, Souza CA, Michelon T, Bilibio JP, Scheffel C \& Cunha-Filho JS 2011 T helper (Th)1, Th2, and Th17 interleukin pathways in infertile patients with minimal/mild endometriosis. Fertility and Sterility 95 2477-2480. (doi:10.1016/j.fertnstert.2011.02.019)

Andres Mde P, Lopes LA, Baracat EC \& Podgaec S 2015 Dienogest in the treatment of endometriosis: systematic review. Archives of Gynecology and Obstetrics 292 523-529. (doi:10.1007/s00404-015-3681-6)

Angioni S, Cofelice V, Pontis A, Tinelli R \& Socolov R 2014 New trends of progestins treatment of endometriosis. Gynecological Endocrinology $\mathbf{3 0}$ 769-773. (doi:10.3109/09513590.2014.950646)

Anglesio MS, Bashashati A, Wang YK, Senz J, Ha G, Yang W, Aniba MR, Prentice LM, Farahani H, Li Chang H et al. 2015 Multifocal endometriotic lesions associated with cancer are clonal and carry a high mutation burden. Journal of Pathology 236 201-209. (doi:10.1002/ path.2015.236.issue-2)
Aoki D, Katsuki Y, Shimizu A, Kakinuma C \& Nozawa S 1994 Successful heterotransplantation of human endometrium in SCID mice. Obstetrics and Gynecology 83 220-228.

Aris A 2010 Endometriosis-associated ovarian cancer: a ten-year cohort study of women living in the Estrie Region of Quebec, Canada. Journal of Ovarian Research 3 2. (doi:10.1186/1757-2215-3-2)

Ayhan A, Mao TL, Seckin T, Wu CH, Guan B, Ogawa H, Futagami M, Mizukami H, Yokoyama Y, Kurman RJ et al. 2012 Loss of ARID1A expression is an early molecular event in tumor progression from ovarian endometriotic cyst to clear cell and endometrioid carcinoma. International Journal of Gynecological Cancer 22 1310-1315. (doi:10.1097/IGC.0b013e31826b5dcc)

Barcz E, Milewski L, Dziunycz P, Kaminski P, Ploski R \& Malejczyk J 2012 Peritoneal cytokines and adhesion formation in endometriosis: an inverse association with vascular endothelial growth factor concentration. Fertility and Sterility 97 1380-1386. (doi:10.1016/j. fertnstert.2012.03.057)

Bedaiwy MA, Patterson B \& Mahajan S 2013 Prevalence of myofascial chronic pelvic pain and the effectiveness of pelvic floor physical therapy. Journal of Reproductive Medicine 58 504-510. (doi:10.1016/j. juro.2015.06.065)

Bedaiwy MA, Dahoud W, Skomorovska-Prokvolit Y, Yi L, Liu JH, Falcone T, Hurd WW \& Mesiano S 2015 Abundance and localization of progesterone receptor isoforms in endometrium in women with and without endometriosis and in peritoneal and ovarian endometriotic implants. Reproductive Sciences 22 1153-1161. (doi:10.1177/1933719115585145)

Bellelis P, Barbeiro DF, Rizzo LV, Baracat EC, Abrao MS \& Podgaec S 2013 Transcriptional changes in the expression of chemokines related to natural killer and T-regulatory cells in patients with deep infiltrative endometriosis. Fertility and Sterility 99 1987-1993. (doi:10.1016/j. fertnstert.2013.02.038)

Bersinger NA, Dechaud H, McKinnon B \& Mueller MD 2012 Analysis of cytokines in the peritoneal fluid of endometriosis patients as a function of the menstrual cycle stage using the Bio-Plex(R) platform. Archives of Physiology and Biochemistry 118 210-218. (doi:10.3109/13813455.20 12.687003)

Beste MT, Pfaffle-Doyle N, Prentice EA, Morris SN, Lauffenburger DA, Isaacson KB \& Griffith LG 2014 Molecular network analysis of endometriosis reveals a role for c-Jun-regulated macrophage activation. Science Translational Medicine 6 222ra16. (doi:10.1126/ scitranslmed.3007988)

Bonocher CM, Montenegro ML, Rosa ESJC, Ferriani RA \& Meola J 2014 Endometriosis and physical exercises: a systematic review. Reproductive Biology and Endocrinology 12 4. (doi:10.1186/1477-7827-12-4)

Bourlev V, Iljasova N, Adamyan L, Larsson A \& Olovsson M 2010 Signs of reduced angiogenic activity after surgical removal of deeply infiltrating endometriosis. Fertility and Sterility 94 52-57. (doi:10.1016/j. fertnstert.2009.02.019)

Boyraz G, Selcuk I, Yazicioglu A \& Tuncer ZS 2013 Ovarian carcinoma associated with endometriosis. European Journal of Obstetrics, Gynecology, and Reproductive Biology 170 211-213. (doi:10.1016/j. ejogrb.2013.06.001)

Braza-Boils A, Gilabert-Estelles J, Ramon LA, Gilabert J, MariAlexandre J, Chirivella M, Espana F \& Estelles A 2013 Peritoneal fluid reduces angiogenesis-related microRNA expression in cell cultures of endometrial and endometriotic tissues from women with endometriosis. PLOS ONE 8 e62370. (doi:10.1371/journal.pone.0062370)

Braza-Boils A, Mari-Alexandre J, Gilabert J, Sanchez-Izquierdo D, Espana F, Estelles A \& Gilabert-Estelles J 2014 MicroRNA expression profile in endometriosis: its relation to angiogenesis and fibrinolytic factors. Hum Reproduction 29 978-988. (doi:10.1093/humrep/deu019)

Braza-Boils A, Salloum-Asfar S, Mari-Alexandre J, Arroyo AB, GonzalezConejero R, Barcelo-Molina M, Garcia-Oms J, Vicente V, Estelles A, Gilabert-Estelles J et al. 2015 Peritoneal fluid modifies the microRNA expression profile in endometrial and endometriotic cells from women with endometriosis. Human Reproduction 30 2292-2302. (doi:10.1093/ humrep/dev204)

Brinton LA, Gridley G, Persson I, Baron J \& Bergqvist A 1997 Cancer risk after a hospital discharge diagnosis of endometriosis. American Journal of Obstetrics and Gynecology 176 572-579. (doi:10.1016/S00029378(97)70550-7) 
Brinton LA, Sakoda LC, Sherman ME, Frederiksen K, Kjaer SK, Graubard BI, Olsen JH \& Mellemkjaer L 2005 Relationship of benign gynecologic diseases to subsequent risk of ovarian and uterine tumors. Cancer Epidemiology, Biomarkers \& Prevention 14 2929-2935. (doi:10.1158/1055-9965.EPI-05-0394)

Brown J \& Farquhar C 2015 An overview of treatments for endometriosis. JAMA 313 296-297. (doi:10.1001/jama.2014.17119)

Bruner-Tran K, McConaha M \& Osteen K 2012 Models of endometriosis: animal models I - rodent-based chimeric models. In Endometriosis: Science and Practice. Chichester, UK: Wiley-Blackwell. (doi:10.1002/9781444398519.ch26)

Bukulmez O, Hardy DB, Carr BR, Word RA \& Mendelson CR 2008 Inflammatory status influences aromatase and steroid receptor expression in endometriosis. Endocrinology 149 1190-1204. (doi:10.1210/ en.2007-0665)

Bulun SE 2009 Endometriosis. New England Journal of Medicine $360268-$ 279. (doi:10.1056/NEJMra0804690)

Bulun SE, Monsavais D, Pavone ME, Dyson M, Xue Q, Attar E, Tokunaga H \& Su EJ 2012 Role of estrogen receptor-beta in endometriosis. Seminars in Reproductive Medicine 30 39-45. (doi:10.1055/s-0031-1299596)

Bulun SE, Monsivais D, Kakinuma T, Furukawa Y, Bernardi L, Pavone ME \& Dyson M 2015 Molecular biology of endometriosis: from aromatase to genomic abnormalities. Seminars in Reproductive Medicine 33220 224. (doi:10.1055/s-0035-1554053)

Burney RO, Talbi S, Hamilton AE, Vo KC, Nyegaard M, Nezhat CR, Lessey BA \& Giudice LC 2007 Gene expression analysis of endometrium reveals progesterone resistance and candidate susceptibility genes in women with endometriosis. Endocrinology 148 3814-3826. (doi:10.1210/en.2006-1692)

Burns KA, Rodriguez KF, Hewitt SC, Janardhan KS, Young SL \& Korach KS 2012 Role of estrogen receptor signaling required for endometriosis-like lesion establishment in a mouse model. Endocrinology 153 3960-3971. (doi:10.1210/en.2012-1294)

Carmona F, Chapron C, Martinez-Zamora MA, Santulli P, Rabanal A, Martinez-Florensa M, Lozano F \& Balasch J 2012 Ovarian endometrioma but not deep infiltrating endometriosis is associated with increased serum levels of interleukin-8 and interleukin-6. Journal of Reproductive Immunology 95 80-86. (doi:10.1016/j.jri.2012.06.001)

Carr BJ, Ochoa L, Rankin D \& Owens BD 2009 Biologic response to orthopedic sutures: a histologic study in a rabbit model. Orthopedics 32 828. (doi:10.3928/01477447-20090922-11)

Carr B, Dmowski WP, O'Brien C, Jiang P, Burke J, Jimenez R, Garner E \& Chwalisz K 2014 Elagolix, an oral GnRH antagonist, versus subcutaneous depot medroxyprogesterone acetate for the treatment of endometriosis: effects on bone mineral density. Reproductive Sciences 21 1341-1351. (doi:10.1177/1933719114549848)

Chen SQ, Li JB, Jiang HY, Yuan L, Niu G \& Yao SZ 2013a Expression of human beta-defensin-2 in the eutopic and ectopic endometrial tissues in patients with endometriosis. Archives of Gynecology and Obstetrics 287 1151-1157. (doi:10.1007/s00404-012-2686-7)

Chen YJ, Wu HH, Liau WT, Tsai CY, Tsai HW, Chao KC, Sung YJ \& Li HY $2013 b$ A tumor necrosis factor-alpha inhibitor reduces the embryotoxic effects of endometriotic peritoneal fluid. Fertility and Sterility $\mathbf{1 0 0}$ 1476-1485. (doi:10.1016/j.fertnstert.2013.07.1985)

Chen S, Wu RF, Su L, Zhou WD, Zhu MB \& Chen QH 2014 Lipoxin A4 regulates expression of the estrogen receptor and inhibits 17 betaestradiol induced p38 mitogen-activated protein kinase phosphorylation in human endometriotic stromal cells. Fertility and Sterility 102 264-271. (doi:10.1016/j.fertnstert.2014.03.029)

Chene G, Ouellet V, Rahimi K, Barres V, Provencher D \& Mes-Masson AM 2015 The ARID1A pathway in ovarian clear cell and endometrioid carcinoma, contiguous endometriosis, and benign endometriosis. International Journal of Gynaecology and Obstetrics 130 27-30. (doi:10.1016/j.ijgo.2015.02.021)

Colette S, Defrere S, Lousse JC, Van Langendonckt A, Gotteland JP, Loumaye E \& Donnez J 2011 Inhibition of steroid sulfatase decreases endometriosis in an in vivo murine model. Human Reproduction 26 1362-1370. (doi:10.1093/humrep/der079)

Cummings A \& Metcalf J 1995 Induction of endometriosis in mice: a new model sensitive to estrogen. Reproductive Toxicology 9 233-238. (doi:10.1016/0890-6238(95)00004-T)

D'Hooghe T, Bambra C, Suleman M, Dunselman G, Evers H \& Koninckx P 1994 Development of a model of retrograde menstruation in baboons
(Papio anubis). Fertility and Sterility 62 635-638. (doi:10.1016/S00150282(16)56957-X)

D'Hooghe T, Bambra C, Raeymaekers B, De Jonge I, Lauweryns J \& Koninckx P 1995 Intrapelvic injection of menstrual endometrium causes endometriosis in baboons (Papio cynocephalus and Papio anubis). American Journal of Obstetrics and Gynecology 173 125-134. (doi:10.1016/0002-9378(95)90180-9)

D'hooghe T, Bambra C, De Jonge I, Lauweryns J \& Koninckx P 1996 The prevalence of spontaneous endometriosis in the baboon (Papio anubis, Papio cynocephalus) increases with the duration of captivity. Acta Obstetricia et Gynecologica Scandinavica 75 98-101. (doi:10.3109/00016349609033298)

Daniels JP, Middleton L, Xiong T, Champaneria R, Johnson NP, Lichten EM, Sutton C, Vercellini P, Gray R, Hills RK et al. 2010 Individual patient data meta-analysis of randomized evidence to assess the effectiveness of laparoscopic uterosacral nerve ablation in chronic pelvic pain. Human Reproduction Update 16 568-576. (doi:10.1093/humupd/dmq031)

Davis M, Rauh-Hain JA, Andrade C, Boruta DM 2nd, Schorge JO, Horowitz NS, May T \& del Carmen MG 2014 Comparison of clinical outcomes of patients with clear cell and endometrioid ovarian cancer associated with endometriosis to papillary serous carcinoma of the ovary. Gynecologic Oncology 132 760-766. (doi:10.1016/j. ygyno.2014.01.012)

Delbandi AA, Mahmoudi M, Shervin A, Akbari E, Jeddi-Tehrani M, Sankian M, Kazemnejad S \& Zarnani AH 2013 Eutopic and ectopic stromal cells from patients with endometriosis exhibit differential invasive, adhesive, and proliferative behavior. Fertility and Sterility $\mathbf{1 0 0}$ 761-769. (doi:10.1016/j.fertnstert.2013.04.041)

Duffy JM, Arambage K, Correa FJ, Olive D, Farquhar C, Garry R, Barlow DH \& Jacobson TZ 2014 Laparoscopic surgery for endometriosis. Cochrane Database of Systematic Reviews 4 CD011031. (doi:10.1002/14651858. CD011031.pub2)

Dunselman GA, Vermeulen N, Becker C, Calhaz-Jorge C, D'Hooghe T, De Bie B, Heikinheimo O, Horne AW, Kiesel L, Nap A et al. 2014 ESHRE guideline: management of women with endometriosis. Human Reproduction 29 400-412. (doi:10.1093/humrep/det457)

Dyson MT, Roqueiro D, Monsivais D, Ercan CM, Pavone ME, Brooks DC, Kakinuma T, Ono M, Jafari N, Dai Y \& Bulun SE 2014 Genome-wide DNA methylation analysis predicts an epigenetic switch for GATA factor expression in endometriosis. PLoS Genetics 10 e1004158. (doi:10.1371/ journal.pgen.1004158)

Dzatic-Smiljkovic O, Vasiljevic M, Djukic M, Vugdelic R \& Vugdelic J 2011 Frequency of ovarian endometriosis in epithelial ovarian cancer patients. Clinical and Experimental Obstetrics \& Gynecology 38 394-398.

Elgafor El \& Sharkwy IA 2013 Combination of non-invasive and semiinvasive tests for diagnosis of minimal to mild endometriosis. Archives of Gynecology and Obstetrics 288 793-797. (doi:10.1007/s00404-0132822-z)

Ezzati M \& Carr BR 2015 Elagolix, a novel, orally bioavailable GnRH antagonist under investigation for the treatment of endometriosis-related pain. Womens Health 11 19-28. (doi:10.2217/whe.14.68)

Fassbender A, Vodolazkaia A, Saunders P, Lebovic D, Waelkens E, De Moor B \& D'Hooghe T 2013 Biomarkers of endometriosis. Fertility and Sterility 99 1135-1145. (doi:10.1016/j.fertnstert.2013.01.097)

Fernando S, Soh PQ, Cooper M, Evans S, Reid G, Tsaltas J \& Rombauts L 2013 Reliability of visual diagnosis of endometriosis. Journal of Minimally Invasive Gynecology 20 783-789. (doi:10.1016/j.jmig.2013.04.017)

Flower A, Liu JP, Lewith G, Little P \& Li Q 2012 Chinese herbal medicine for endometriosis. Cochrane Database of Systematic Review 5 CD006568. (doi:10.1002/14651858.CD006568.pub3)

Fritz MA \& Speroff L 2011 Clinical Gynecologic Endocrinology and Infertility. Philadelphia, PA, USA: Lippincott Williams and Wilkins.

Funamizu A, Fukui A, Kamoi M, Fuchinoue K, Yokota M, Fukuhara R \& Mizunuma H 2014 Expression of natural cytotoxicity receptors on peritoneal fluid natural killer cell and cytokine production by peritoneal fluid natural killer cell in women with endometriosis. American Journal of Reproductive Immunology 71 359-367. (doi:10.1111/aji.2014.71. issue-4)

Gadducci A, Lanfredini N \& Tana R 2014 Novel insights on the malignant transformation of endometriosis into ovarian carcinoma. Gynecological Endocrinology 30 612-617. (doi:10.3109/09513590.2014.926325)

Galic V, Coleman RL \& Herzog TJ 2013 Unmet needs in ovarian cancer: dividing histologic subtypes to exploit novel targets and pathways. 
Current Cancer Drug Targets 13 698-707. (doi:10.2174/15680096113 139990002)

Goncalves HF, Zendron C, Cavalcante FS, Aiceles V, Oliveira MA, Manaia JH, Babinski MA \& Ramos CF 2015 Leptin, its receptor and aromatase expression in deep infiltrating endometriosis. Journal of Ovarian Research 8 53. (doi:10.1186/s13048-015-0180-0)

Granese R, Perino A, Calagna G, Saitta S, De Franciscis P, Colacurci N, Triolo O \& Cucinella G 2015 Gonadotrophin-releasing hormone analogue or dienogest plus estradiol valerate to prevent pain recurrence after laparoscopic surgery for endometriosis: a multi-center randomized trial. Acta Obstetricia et Gynecologica Scandinavica 94 637-645. (doi:10.1111/aogs.2015.94.issue-6)

Greaves E, Cousins FL, Murray A, Esnal-Zufiaurre A, Fassbender A, Horne AW \& Saunders PT 2014 A novel mouse model of endometriosis mimics human phenotype and reveals insights into the inflammatory contribution of shed endometrium. American Journal of Pathology 184 1930-1939. (doi:10.1016/j.ajpath.2014.03.011)

Greenberg LH \& Slayden OD 2004 Human endometriotic xenografts in immunodeficient RAG-2/gamma(c)KO mice. American Journal of Obstetrics and Gynecology 190 1788-1795; discussion 1795-1786. (doi:10.1016/j.ajog.2004.02.047)

Grummer R 2012 Models of endometriosis: in vitro and in vivo models. In Endometriosis: Science and Practice. Chichester, UK: Wiley-Blackwell. (doi:10.1002/9781444398519.ch25)

Guo Y, Chen Y, Liu LB, Chang KK, Li H, Li MQ \& Shao J 2013 IL-22 in the endometriotic milieu promotes the proliferation of endometrial stromal cells via stimulating the secretion of CCL2 and IL-8. International Journal of Clinical and Experimental Pathology 6 2011-2020.

Han SJ, Hawkins SM, Begum K, Jung SY, Kovanci E, Qin J, Lydon JP, DeMayo FJ \& O'Malley BW 2012 A new isoform of steroid receptor coactivator-1 is crucial for pathogenic progression of endometriosis. Nature Medicine 18 1102-1111. (doi:10.1038/nm.2826)

Han SJ, Jung SY, Wu SP, Hawkins SM, Park MJ, Kyo S, Qin J, Lydon JP, Tsai SY, Tsai MJ et al. 2015 Estrogen receptor beta modulates apoptosis complexes and the inflammasome to drive the pathogenesis of endometriosis. Cell 163 960-974. (doi:10.1016/j.cell.2015.10.034)

Hansen SO \& Knudsen UB 2013 Endometriosis, dysmenorrhoea and diet. European Journal of Obstetrics, Gynecology, and Reproductive Biology 169 162-171. (doi:10.1016/j.ejogrb.2013.03.028)

Harada T, Momoeda M, Taketani Y, Hoshiai H \& Terakawa N 2008 Low-dose oral contraceptive pill for dysmenorrhea associated with endometriosis: a placebo-controlled, double-blind, randomized trial. Fertility and Sterility 90 1583-1588. (doi:10.1016/j.fertnstert.2007.08.051)

Healey M, Cheng C \& Kaur H 2014 To excise or ablate endometriosis? A prospective randomized double-blinded trial after 5-year follow-up. Journal of Minimally Invasive Gynecology 21 999-1004. (doi:10.1016/j. jmig.2014.04.002)

Herington JL, Crispens MA, Carvalho-Macedo AC, Camargos AF, Lebovic DI, Bruner-Tran KL \& Osteen KG 2011 Development and prevention of postsurgical adhesions in a chimeric mouse model of experimental endometriosis. Fertility and Sterility 95 1295-1301. (doi:10.1016/j.fertnstert.2010.09.017)

Hickey M, Ballard K \& Farquhar C 2014 Endometriosis. BMJ 348 g1752. (doi:10.1136/bmj.g1752)

Hsu AL, Khachikyan I \& Stratton P 2010 Invasive and noninvasive methods for the diagnosis of endometriosis. Clinical Obstetrics and Gynecology 53 413-419. (doi:10.1097/GRF.0b013e3181db7ce8)

Huang HN, Lin MC, Huang WC, Chiang YC \& Kuo KT 2014 Loss of ARID1A expression and its relationship with PI3K-Akt pathway alterations and ZNF217 amplification in ovarian clear cell carcinoma. Modern Pathology 27 983-990. (doi:10.1038/modpathol.2013.216)

Hull ML, Johan MZ, Hodge WL, Robertson SA \& Ingman WV 2012 Hostderived TGFB1 deficiency suppresses lesion development in a mouse model of endometriosis. American Journal of Pathology 180 880-887. (doi:10.1016/j.ajpath.2011.11.013)

Ilad RS, Fleming SD, Murphy CR \& Fazleabas AT 2010 Immunohistochemical study of the ubiquitin-nuclear factor-kB pathway in the endometrium of the baboon (Papio anubis) with and without endometriosis. Reproduction, Fertility, and Development 22 1118-1130. (doi:10.1071/RD08086)

Imai A, Matsunami K, Takagi H \& Ichigo S 2014 Levonorgestrel-releasing intrauterine device used for dysmenorrhea: five-year literature review.
Clinical and Experimental Obstetrics \& Gynecology 41 495-498. (doi:10.12891/ceog17042014)

Juhasz-Boss I, Hofele A, Lattrich C, Buchholz S, Ortmann O \& Malik E 2010 Matrix metalloproteinase messenger RNA expression in human endometriosis grafts cultured on a chicken chorioallantoic membrane. Fertility and Sterility 94 40-45. (doi:10.1016/j.fertnstert.2009.02.052)

Kang YJ, Jeung IC, Park A, Park YJ, Jung H, Kim TD, Lee HG, Choi I \& Yoon SR 2014 An increased level of IL-6 suppresses NK cell activity in peritoneal fluid of patients with endometriosis via regulation of SHP-2 expression. Human Reproduction 29 2176-2189. (doi:10.1093/humrep/ deu172)

Keita M, Bessette P, Pelmus M, Ainmelk Y \& Aris A 2010 Expression of interleukin-1 (IL-1) ligands system in the most common endometriosisassociated ovarian cancer subtypes. Journal of Ovarian Research 33. (doi:10.1186/1757-2215-3-3)

Keita M, AinMelk Y, Pelmus M, Bessette P \& Aris A 2011 Endometrioid ovarian cancer and endometriotic cells exhibit the same alteration in the expression of interleukin-1 receptor II: to a link between endometriosis and endometrioid ovarian cancer. Journal of Obstetrics and Gynaecology Research 37 99-107. (doi:10.1111/jog.2011.37.issue-2)

Khan KN, Kitajima M, Inoue T, Fujishita A, Nakashima M \& Masuzaki H 201517 beta-estradiol and lipopolysaccharide additively promote pelvic inflammation and growth of endometriosis. Reproductive Sciences 22 585-594. (doi:10.1177/1933719114556487)

Kim HS, Kim TH, Chung HH \& Song YS 2014 Risk and prognosis of ovarian cancer in women with endometriosis: a meta-analysis. British Journal of Cancer 110 1878-1890. (doi:10.1038/bjc.2014.29)

King C, Barbara C, Prentice A, Brenton J \& Charnock-Jones D 2016 Models of endometriosis and their utility in studying progression to ovarian clear cell carcinoma. Journal of Pathology 238 185-196. (doi:10.1002/ path.4657)

Kinugasa S, Shinohara K \& Wakatsuki A 2011 Increased asymmetric dimethylarginine and enhanced inflammation are associated with impaired vascular reactivity in women with endometriosis. Atherosclerosis 219 784-788. (doi:10.1016/j.atherosclerosis.2011.08.005)

Kobayashi H, Yamada Y, Kanayama S, Furukawa N, Noguchi T, Haruta S, Yoshida S, Sakata M, Sado T \& Oi H 2009 The role of hepatocyte nuclear factor-1beta in the pathogenesis of clear cell carcinoma of the ovary. International Journal of Gynecological Cancer 19 471-479. (doi:10.1111/IGC.0b013e3181a19eca)

Kondi-Pafiti A, Papakonstantinou E, lavazzo C, Grigoriadis C, Salakos N \& Gregoriou O 2012 Clinicopathological characteristics of ovarian carcinomas associated with endometriosis. Archives of Gynecology and Obstetrics 285 479-483. (doi:10.1007/s00404-011-1957-z)

Kong S, Zhang YH, Liu CF, Tsui I, Guo Y, Ai BB \& Han FJ 2014 The complementary and alternative medicine for endometriosis: a review of utilization and mechanism. Evidence-Based Complementary and Alternative Medicine 2014 146383. (doi:10.1155/2014/146383)

Kulak J Jr, Fischer C, Komm B \& Taylor HS 2011 Treatment with bazedoxifene, a selective estrogen receptor modulator, causes regression of endometriosis in a mouse model. Endocrinology 152 3226-3232. (doi:10.1210/en.2010-1010)

Kumar S, Munkarah A, Arabi H, Bandyopadhyay S, Semaan A, Hayek K, Garg G, Morris R \& Ali-Fehmi R 2011 Prognostic analysis of ovarian cancer associated with endometriosis. American Journal of Obstetrics and Gynecology 204 63.e1-63.e7. (doi:10.1016/j.ajog.2010.08.017)

Kumar R, Clerc AC, Gori I, Russell R, Pellegrini C, Govender L, Wyss JC, Golshayan D \& Canny GO 2014 Lipoxin A(4) prevents the progression of de novo and established endometriosis in a mouse model by attenuating prostaglandin $\mathrm{E}(2)$ production and estrogen signaling. PLOS ONE 9 e89742. (doi:10.1371/journal.pone.0089742)

Lai CR, Hsu CY, Chen YJ, Yen MS, Chao KC \& Li AF 2013 Ovarian cancers arising from endometriosis: a microenvironmental biomarker study including ER, HNF1ss, p53, PTEN, BAF250a, and COX-2. Journal of the Chinese Medical Association 76 629-634. (doi:10.1016/j. jcma.2013.07.008)

Lebovic DI, Kavoussi SK, Lee J, Banu SK \& Arosh JA 2013 PPARgamma activation inhibits growth and survival of human endometriotic cells by suppressing estrogen biosynthesis and PGE2 signaling. Endocrinology 154 4803-4813. (doi:10.1210/en.2013-1168)

Leconte $M$, Chouzenoux S, Nicco C, Chereau C, Arkwright S, Santulli P, Weill B, Chapron C, Dousset B \& Batteux F 2014 Role of the 
CXCL12-CXCR4 axis in the development of deep rectal endometriosis. Journal of Reproductive Immunology 103 45-52. (doi:10.1016/j. jri.2013.12.121)

Lee DH, Kim SC, Joo JK, Kim HG, Na YJ, Kwak JY \& Lee KS 2012 Effects of 17 beta-estradiol on the release of monocyte chemotactic protein-1 and MAPK activity in monocytes stimulated with peritoneal fluid from endometriosis patients. Journal of Obstetrics and Gynaecology Research 38 516-525. (doi:10.1111/jog.2012.38.issue-3)

Lee AW, Templeman C, Stram DA, Beesley J, Tyrer J, Berchuck A, Pharoah PP, Chenevix-Trench G, Pearce CL \& Ovarian Cancer Association C 2016 Evidence of a genetic link between endometriosis and ovarian cancer. Fertility and Sterility 105 35-43 e10. (doi:10.1016/j. fertnstert.2015.09.023)

Leone Roberti Maggiore U, Scala C, Remorgida V, Venturini PL, Del Deo F, Torella M, Colacurci N, Salvatore S, Ferrari S, Papaleo E et al. 2014 Triptorelin for the treatment of endometriosis. Expert Opinion on Pharmacotherapy 15 1153-1179. (doi:10.1517/14656566.2014. 916279)

Lin W, Chen S, Li M, Wang B, Qu X \& Zhang Y 2010 Expression of macrophage migration inhibitory factor in human endometriosis: relation to disease stage, menstrual cycle and infertility. Journal of Obstetrics and Gynaecology Research 36 344-351. (doi:10.1111/(ISSN)1447-0756)

Lowery WJ, Schildkraut JM, Akushevich L, Bentley R, Marks JR, Huntsman D \& Berchuck A 2012 Loss of ARID1A-associated protein expression is a frequent event in clear cell and endometrioid ovarian cancers. International Journal of Gynecological Cancer 22 9-14. (doi:10.1097/IGC.0b013e318231f140)

Lu Z, Zhang W, Jiang S, Zou J \& Li Y 2014a Effect of lesion location on endometriotic adhesion and angiogenesis in SCID mice. Archives of Gynecology and Obstetrics 289 823-830. (doi:10.1007/s00404-0133048-9)

Lu Z, Zhang W, Jiang S, Zou J \& Li Y 2014b Effect of oxygen tensions on the proliferation and angiogenesis of endometriosis heterograft in severe combined immunodeficiency mice. Fertility and Sterility 101 568-576. (doi:10.1016/j.fertnstert.2013.10.039)

Luk J, Seval Y, Ulukus M, Ulukus EC, Arici A \& Kayisli UA 2010 Regulation of monocyte chemotactic protein-1 expression in human endometrial endothelial cells by sex steroids: a potential mechanism for leukocyte recruitment in endometriosis. Reproductive Sciences 17 278-287. (doi:10.1177/1933719109352380)

Maas J, Groothuis P, Dunselman G, de Goeij A, Struijker-Boudier H \& Evers J 2001 Development of endometriosis-like lesions after transplantation of human endometrial fragments onto the chick embryo chorioallantoic membrane. Human Reproduction 16 627-631. (doi:10.1093/humrep/16.4.627)

Machado DE, Berardo PT, Palmero CY \& Nasciutti LE 2010 Higher expression of vascular endothelial growth factor (VEGF) and its receptor VEGFR-2 (Flk-1) and metalloproteinase-9 (MMP-9) in a rat model of peritoneal endometriosis is similar to cancer diseases. Journal of Experimental \& Clinical Cancer Research 29 4. (doi:10.1186/1756-996629-4)

Machado DE, Palumbo A Jr, Santos JM, Mattos RM, dos Santos TA, Seabra SH, Boldrini Lda C, Perini JA \& Nasciutti LE 2014 A GFP endometriosis model reveals important morphological characteristics of the angiogenic process that govern benign and malignant diseases. Histology and Histopathology 29 903-912. (doi:10.14670/HH-29.903)

Malhotra N, Karmakar D, Tripathi V, Luthra K \& Kumar S 2012 Correlation of angiogenic cytokines-leptin and IL-8 in stage, type and presentation of endometriosis. Gynecological Endocrinology 28 224-227. (doi:10.31 09/09513590.2011.593664)

Margari KM, Zafiropoulos A, Hatzidaki E, Giannakopoulou C, Arici A \& Matalliotakis I 2013 Peritoneal fluid concentrations of beta-chemokines in endometriosis. European Journal of Obstetrics, Gynecology, and Reproductive biology 169 103-107. (doi:10.1016/j.ejogrb.2013.02.010)

Matsumoto T, Yamazaki M, Takahashi H, Kajita S, Suzuki E, Tsuruta T \& Saegusa M 2015 Distinct beta-catenin and PIK3CA mutation profiles in endometriosis-associated ovarian endometrioid and clear cell carcinomas. American Journal of Clinical Pathology 144 452-463. (doi:10.1309/AJCPZ5T2POOFMQVN)

McConechy MK, Ding J, Senz J, Yang W, Melnyk N, Tone AA, Prentice LM, Wiegand KC, McAlpine JN, Shah SP et al. 2014 Ovarian and endometrial endometrioid carcinomas have distinct CTNNB1 and
PTEN mutation profiles. Modern Pathology 27 128-134. (doi:10.1038/ modpathol.2013.107)

Mier-Cabrera J, Jimenez-Zamudio L, Garcia-Latorre E, Cruz-Orozco O \& Hernandez-Guerrero C 2011 Quantitative and qualitative peritoneal immune profiles, T-cell apoptosis and oxidative stress-associated characteristics in women with minimal and mild endometriosis. British Journal of Obstetrics \& Gynaecology 118 6-16. (doi:10.1111/j.14710528.2010.02777.x)

Milewski L, Dziunycz P, Barcz E, Radomski D, Roszkowski PI, KorczakKowalska G, Kaminski P \& Malejczyk J 2011 Increased levels of human neutrophil peptides 1, 2, and 3 in peritoneal fluid of patients with endometriosis: association with neutrophils, T cells and IL-8. Journal of Reproductive Immunology 91 64-70. (doi:10.1016/j.jri.2011.05.008)

Monsivais D, Dyson MT, Yin P, Coon JS, Navarro A, Feng G, Malpani SS, Ono M, Ercan CM, Wei J et al. 2014 ERbeta- and prostaglandin E2regulated pathways integrate cell proliferation via Ras-like and estrogenregulated growth inhibitor in endometriosis. Molecular Endocrinology 28 1304-1315. (doi:10.1210/me.2013-1421)

Munksgaard PS \& Blaakaer J 2012 The association between endometriosis and ovarian cancer: a review of histological, genetic and molecular alterations. Gynecologic Oncology 124 164-169. (doi:10.1016/j. ygyno.2011.10.001)

Munoz-Hernando L, Munoz-Gonzalez JL, Marqueta-Marques L, Alvarez-Conejo C, Tejerizo-Garcia A, Lopez-Gonzalez G, Villegas-Munoz E, Martin-Jimenez A \& Jimenez-Lopez JS 2015 Endometriosis: alternative methods of medical treatment. International Journal of Womens Health 7 595-603. (doi:10.2147/IJWH.S78829)

Muzii L, Di Tucci C, Achilli C, Di Donato V, Musella A, Palaia I \& Panici PB 2016 Continuous versus cyclic oral contraceptives after laparoscopic excision of ovarian endometriomas: a systematic review and metaanalysis. American Journal of Obstetrics and Gynecology 214 203-211. (doi:10.1016/j.ajog.2015.08.074)

Nap AW, Dunselman GA, de Goeij AF, Evers JL \& Groothuis PG 2004 Inhibiting MMP activity prevents the development of endometriosis in the chicken chorioallantoic membrane model. Human Reproduction 19 2180-2187. (doi:10.1093/humrep/deh408)

Nap AW, Dunselman GA, Griffioen AW, Mayo KH, Evers JL \& Groothuis PG 2005 Angiostatic agents prevent the development of endometriosis-like lesions in the chicken chorioallantoic membrane. Fertility and Sterility 83 793-795. (doi:10.1016/j.fertnstert.2004.06.080)

Naqvi H, Sakr S, Presti T, Krikun G, Komm B \& Taylor HS 2014 Treatment with bazedoxifene and conjugated estrogens results in regression of endometriosis in a murine model. Biology of Reproduction 90121. (doi:10.1095/biolreprod.113.114165)

Ness RB 2003 Endometriosis and ovarian cancer: thoughts on shared pathophysiology. American Journal of Obstetrics and Gynecology 189 280-294. (doi:10.1067/mob.2003.408)

Nezhat F, Datta MS, Hanson V, Pejovic T, Nezhat C \& Nezhat C 2008 The relationship of endometriosis and ovarian malignancy: a review. Fertility and Sterility 90 1559-1570. (doi:10.1016/j.fertnstert.2008.08.007)

Novella-Maestre E, Herraiz S, Vila-Vives JM, Carda C, Ruiz-Sauri A \& Pellicer A 2012 Effect of antiangiogenic treatment on peritoneal endometriosis-associated nerve fibers. Fertility and Sterility 981209 1217. (doi:10.1016/j.fertnstert.2012.07.1103)

Page-McCaw A, Ewald AJ \& Werb Z 2007 Matrix metalloproteinases and the regulation of tissue remodelling. Nature Reviews. Molecular Cell Biology 8 221-233. (doi:10.1038/nrm2125)

Palmer SS, Altan M, Denis D, Tos EG, Gotteland JP, Osteen KG, Bruner-Tran KL \& Nataraja SG 2016 Bentamapimod (JNK Inhibitor AS602801) Induces Regression of Endometriotic Lesions in Animal Models. Reproductive Sciences 23 11-23. (doi:10.1177/1933719 115600553)

Pearce CL, Templeman C, Rossing MA, Lee A, Near AM, Webb PM, Nagle CM, Doherty JA, Cushing-Haugen KL, Wicklund KG et al. 2012 Association between endometriosis and risk of histological subtypes of ovarian cancer: a pooled analysis of case-control studies. Lancet Oncology 13 385-394. (doi:10.1016/S1470-2045(11)70404-1)

Pellegrini C, Gori I, Achtari C, Hornung D, Chardonnens E, Wunder D, Fiche M \& Canny GO 2012 The expression of estrogen receptors as well as GREB1, C-MYC, and cyclin D1, estrogen-regulated genes implicated in proliferation, is increased in peritoneal endometriosis. Fertility and Sterility 98 1200-1208. (doi:10.1016/j.fertnstert.2012.06.056) 
Podgaec S, Rizzo LV, Fernandes LF, Baracat EC \& Abrao MS 2012 CD4(+) CD25(high) Foxp3(+) cells increased in the peritoneal fluid of patients with endometriosis. American Journal of Reproductive Immunology $\mathbf{6 8}$ 301-308. (doi:10.1111/aji.2012.68.issue-4)

Posadzka E, Jach R, Pitynski K \& Jablonski MJ 2015 Treatment efficacy for pain complaints in women with endometriosis of the lesser pelvis after laparoscopic electroablation vs. $\mathrm{CO}_{2}$ laser ablation. Lasers in Medical Science 30 147-152. (doi:10.1007/s10103-014-1630-4)

Practice Committee of the American Society for Reproductive $M$ 2014 Treatment of pelvic pain associated with endometriosis: a committee opinion. Fertility and Sterility 101 927-935. (doi:10.1016/j. fertnstert.2014.02.012)

Rathore N, Kriplani A, Yadav RK, Jaiswal U \& Netam R 2014 Distinct peritoneal fluid ghrelin and leptin in infertile women with endometriosis and their correlation with interleukin- 6 and vascular endothelial growth factor. Gynecological Endocrinology 30 671-675. (doi:10.3109/095135 90.2014.920318)

Ricci AG, Olivares CN, Bilotas MA, Meresman GF \& Baranao RI 2011 Effect of vascular endothelial growth factor inhibition on endometrial implant development in a murine model of endometriosis. Reproductive Sciences 18 614-622. (doi:10.1177/1933719110395406)

Rossing MA, Cushing-Haugen KL, Wicklund KG, Doherty JA \& Weiss NS 2008 Risk of epithelial ovarian cancer in relation to benign ovarian conditions and ovarian surgery. Cancer Causes Control 19 1357-1364. (doi:10.1007/s10552-008-9207-9)

Rubi-Klein K, Kucera-Sliutz E, Nissel H, Bijak M, Stockenhuber D, Fink M \& Wolkenstein E 2010 Is acupuncture in addition to conventional medicine effective as pain treatment for endometriosis? A randomised controlled cross-over trial. European Journal of Obstetrics, Gynecology, and Reproductive Biology 153 90-93. (doi:10.1016/j. ejogrb.2010.06.023)

Ruiz A, Salvo VA, Ruiz LA, Baez P, Garcia M \& Flores I 2010 Basal and steroid hormone-regulated expression of CXCR4 in human endometrium and endometriosis. Reproductive Sciences 17 894-903. (doi:10.1177/1933719110379920)

Sabbaghi M, Aram R, Roustaei H, Fadavi Islam M, Daneshvar $M$, Castano AR \& Haghparast A 2014 IL-17A concentration of seminal plasma and follicular fluid in infertile men and women with various clinical diagnoses. Immunological Investigations 43 617-626. (doi:10. 3109/08820139.2014.909453)

Samartzis EP, Samartzis N, Noske A, Fedier A, Caduff R, Dedes KJ, Fink D \& Imesch P 2012 Loss of ARID1A/BAF250a-expression in endometriosis: a biomarker for risk of carcinogenic transformation? Modern Pathology 25 885-892. (doi:10.1038/modpathol.2011.217)

Sampson JA 1925 Endometrial carcinoma of the ovary, arising in endometrial tissue in that organ. Archives of Surgery 10 1-72. (doi:10.1001/archsurg.1925.01120100007001)

Sampson J 1927a Metastatic or Embolic Endometriosis, due to the Menstrual Dissemination of Endometrial Tissue into the Venous Circulation. American Journal of Pathology 3 93-110.143.

Sampson J 1927b Peritoneal endometriosis due to the menstrual dissemination of endometrial tissue into the peritoneal cavity. American Journal of Obstetrics and Gynecology 14 422-469.

Santulli P, Borghese B, Chouzenoux S, Streuli I, Borderie D, de Ziegler D, Weill B, Chapron C \& Batteux F 2013 Interleukin-19 and interleukin-22 serum levels are decreased in patients with ovarian endometrioma. Fertility and Sterility 99 219-226. (doi:10.1016/j.fertnstert.2012.08.055)

Scarfone G, Bergamini A, Noli S, Villa A, Cipriani S, Taccagni G, Vigano P, Candiani M, Parazzini F \& Mangili G 2014 Characteristics of clear cell ovarian cancer arising from endometriosis: a two center cohort study. Gynecologic Oncology 133 480-484. (doi:10.1016/j. ygyno.2014.03.017)

Schorge JO, Modesitt SC, Coleman RL, Cohn DE, Kauff ND, Duska LR \& Herzog TJ 2010 SGO White Paper on ovarian cancer: etiology, screening and surveillance. Gynecologic Oncology 119 7-17. (doi:10.1016/j. ygyno.2010.06.003)

Scott RB 1953 Malignant changes in endometriosis. Obstetrics and Gynecology 2 283-289.

Scott R, Te Linde R \& Wharton L 1953 Further studies on experimental endometriosis. American Journal of Obstetrics and Gynecology $\mathbf{6 6}$ 1082-1103.
Sikora J, Mielczarek-Palacz A \& Kondera-Anasz Z 2012 Imbalance in cytokines from interleukin-1 family - role in pathogenesis of endometriosis. American Journal of Reproductive Immunology $\mathbf{6 8}$ 138-145. (doi:10.1111/aji.2012.68.issue-2)

Sillem M, Hahn U, Coddington C, Gordon K, Runnebaum B \& Hodgen G 1996 Ectopic growth of endometrium depends on its structural integrity and proteolytic activity in the cynomolgus monkey (Macaca fascicularis) model of endometriosis. Fertility and Sterility 66 468-473. (doi:10.1016/ S0015-0282(16)58521-5)

Somigliana E, Vigano P, Rossi G, Carinelli S, Vignali M \& PaninaBordignon P 1999 Endometrial ability to implant in ectopic sites can be prevented by interleukin-12 in a murine model of endometriosis. Human Reproduction 14 2944-2950. (doi:10.1093/humrep/14.12.2944)

Strowitzki T, Faustmann T, Gerlinger C, Schumacher U, Ahlers C \& Seitz C 2015 Safety and tolerability of dienogest in endometriosis: pooled analysis from the European clinical study program. International Journal of Womens Health 7 393-401. (doi:10.2147/IJWH.S77202)

Styer AK, Sullivan BT, Puder M, Arsenault D, Petrozza JC, Serikawa T, Chang S, Hasan T, Gonzalez RR \& Rueda BR 2008 Ablation of leptin signaling disrupts the establishment, development, and maintenance of endometriosis-like lesions in a murine model. Endocrinology $\mathbf{1 4 9}$ 506-514. (doi:10.1210/en.2007-1225)

Suganuma I, Mori T, Ito F, Tanaka Y, Sasaki A, Matsuo S, Kusuki I \& Kitawaki J 2014 Peroxisome proliferator-activated receptor gamma, coactivator 1 alpha enhances local estrogen biosynthesis by stimulating aromatase activity in endometriosis. Journal of Clinical Endocrinology and Metabolism 99 E1191-1198. (doi:10.1210/jc.2013-2525)

Syrop CH \& Halme J 1987 Peritoneal fluid environment and infertility. Fertility and Sterility 48 1-9. (doi:10.1016/S0015-0282(16)59280-2)

Szubert M, Suzin J, Duechler M, Szulawska A, Czyz M \& Kowalczyk-Amico K 2014 Evaluation of selected angiogenic and inflammatory markers in endometriosis before and after danazol treatment. Reproduction, Fertility, and Development 26 414-420. (doi:10.1071/RD12258)

Tanmahasamut P, Rattanachaiyanont M, Angsuwathana S, Techatraisak K, Indhavivadhana S \& Leerasiri P 2012 Postoperative levonorgestrelreleasing intrauterine system for pelvic endometriosis-related pain: a randomized controlled trial. Obstetrics and Gynecology 119 519-526. (doi:10.1097/AOG.0b013e31824264c3)

Tao Y, Zhang Q, Huang W, Zhu H, Zhang D \& Luo W 2011 The peritoneal leptin, MCP-1 and TNF-alpha in the pathogenesis of endometriosisassociated infertility. American Journal of Reproductive Immunology $\mathbf{6 5}$ 403-406. (doi:10.1111/j.1600-0897.2010.00920.x)

Te Linde R \& Scott R 1950 Experimental endometriosis. American Journal of Obstetrics and Gynecology 60 1147-1173. (doi:10.1016/00029378(50)90517-5)

Tirado-Gonzalez I, Barrientos G, Tariverdian N, Arck P, Garcia M, Klapp B \& Blois S 2010 Endometriosis research: animal models for the study of a complex disease. Journal of Reproductive Immunology 86 141-147. (doi:10.1016/j.jri.2010.05.001)

Veillat V, Sengers V, Metz CN, Roger T, Leboeuf M, Mailloux J \& Akoum A 2012 Macrophage migration inhibitory factor is involved in a positive feedback loop increasing aromatase expression in endometriosis. American Journal of Pathology 181 917-927. (doi:10.1016/j. ajpath.2012.05.018)

Velasco I, Acien P, Campos A, Acien MI \& Ruiz-Macia E 2010 Interleukin-6 and other soluble factors in peritoneal fluid and endometriomas and their relation to pain and aromatase expression. Journal of Reproductive Immunology 84 199-205. (doi:10.1016/j.jri.2009.11.004)

Vernon M \& Wilson E 1985 Studies on the surgical induction of endometriosis in the rat. Fertility and Sterility 44 684-694. (doi:10.1016/ S0015-0282(16)48988-0)

Virani S, Edwards AK, Thomas R, Childs T \& Tayade C 2013 Blocking of stromal cell-derived factor- 1 reduces neoangiogenesis in human endometriosis lesions in a mouse model. American Journal of Reproductive Immunology 70 386-397. (doi:10.1111/aji.12134)

Wang XQ, Yu J, Luo XZ, Shi YL, Wang Y, Wang L \& Li DJ 2010 The high level of RANTES in the ectopic milieu recruits macrophages and induces their tolerance in progression of endometriosis. Journal of Molecular Endocrinology 45 291-299. (doi:10.1677/JME-09-0177)

Wei JJ, William J \& Bulun S 2011 Endometriosis and ovarian cancer: a review of clinical, pathologic, and molecular aspects. International 
Journal of Gynecological Pathology 30 553-568. (doi:10.1097/ PGP.0b013e31821f4b85)

Weng Q, Ding ZM, Lv XL, Yang DX, Song YZ, Wang FF, Ye YH \& Qu F 2015 Chinese medicinal plants for advanced endometriosis after conservative surgery: a prospective, multi-center and controlled trial. International Journal of Clinical and Experimental Medicine 8 11307-11311.

Wickiewicz D, Chrobak A, Gmyrek GB, Halbersztadt A, Gabrys MS, Goluda M \& Chelmonska-Soyta A 2013 Diagnostic accuracy of interleukin-6 levels in peritoneal fluid for detection of endometriosis. Archives of Gynecology and Obstetrics 288 805-814. (doi:10.1007/ s00404-013-2828-6)

Wiegand KC, Shah SP, Al-Agha OM, Zhao Y, Tse K, Zeng T, Senz J, McConechy MK, Anglesio MS, Kalloger SE et al. 2010 ARID1 A mutations in endometriosis-associated ovarian carcinomas. New England Journal of Medicine 363 1532-1543. (doi:10.1056/NEJMoa1008433)

Wiegand KC, Lee AF, Al-Agha OM, Chow C, Kalloger SE, Scott DW, Steidl C, Wiseman SM, Gascoyne RD, Gilks B et al. 2011 Loss of BAF250a (ARID1A) is frequent in high-grade endometrial carcinomas. Journal of Pathology 224 328-333. (doi:10.1002/path.v224.3)

Worley MJ Jr, Liu S, Hua Y, Kwok JS, Samuel A, Hou L, Shoni M, Lu S, Sandberg EM, Keryan A et al. 2015 Molecular changes in endometriosisassociated ovarian clear cell carcinoma. European Journal of Cancer $\mathbf{5 1}$ 1831-1842. (doi:10.1016/j.ejca.2015.05.011)

Wu MH, Lu CW, Chang FM \& Tsai SJ 2012 Estrogen receptor expression affected by hypoxia inducible factor-1alpha in stromal cells from patients with endometriosis. Taiwanese Journal of Obstetrics \& Gynecology 51 50-54. (doi:10.1016/j.tjog.2012.01.010)

Xu H, Becker CM, Lui WT, Chu CY, Davis TN, Kung AL, Birsner AE, D'Amato RJ, Wai Man GC \& Wang CC 2011 Green tea epigallocatechin3-gallate inhibits angiogenesis and suppresses vascular endothelial growth factor $\mathrm{C} /$ vascular endothelial growth factor receptor 2 expression and signaling in experimental endometriosis in vivo. Fertility and Sterility 96 1021-1028. (doi:10.1016/j.fertnstert.2011.07.008)

Xu H, Zhang T, Man GC, May KE, Becker CM, Davis TN, Kung AL, Birsner AE, D'Amato RJ, Wong AW et al. 2013 Vascular endothelial growth factor $C$ is increased in endometrium and promotes endothelial functions, vascular permeability and angiogenesis and growth of endometriosis. Angiogenesis 16 541-551. (doi:10.1007/s10456-013-9333-1)

Yang Y, Zhang X, Zhou C, Huang X, Lin J \& Xu H 2013 Elevated immunoreactivity of RANTES and CCR1 correlate with the severity of stages and dysmenorrhea in women with deep infiltrating endometriosis. Acta Histochemica 115 434-439. (doi:10.1016/j.acthis.2012.10.006)

Yeo SG, Won YS, Lee HY, Kim YI, Lee JW \& Park DC 2013 Increased expression of pattern recognition receptors and nitric oxide synthase in patients with endometriosis. International Journal of Medical Sciences 10 1199-1208. (doi:10.7150/ijms.5169)

Young VJ, Brown JK, Maybin J, Saunders PT, Duncan WC \& Horne AW 2014a Transforming growth factor-beta induced Warburg-like metabolic reprogramming may underpin the development of peritoneal endometriosis. Journal of Clinical Endocrinology and Metabolism 99 3450-3459. (doi:10.1210/jc.2014-1026)

Young VJ, Brown JK, Saunders PT, Duncan WC \& Horne AW 2014b The peritoneum is both a source and target of TGF-beta in women with endometriosis. PLOS ONE e106773. (doi:10.1371/journal. pone.0106773)

Zamah N, Dodson M, Stephens L, Buttram V, Besch P \& Kaufman R 1984 Transplantation of normal and ectopic human endometrial tissue into athymic nude mice. American Journal of Obstetrics and Gynecology 149 591-597. (doi:10.1016/0002-9378(84)90240-0)

Zanetta GM, Webb MJ, Li H \& Keeney GL 2000 Hyperestrogenism: a relevant risk factor for the development of cancer from endometriosis. Gynecologic Oncology 79 18-22. (doi:10.1006/gyno.2000.5905)

Zhao Y, Gong P, Chen Y, Nwachukwu JC, Srinivasan S, Ko C, Bagchi MK, Taylor RN, Korach KS, Nettles KW, Katzenellenbogen JA \& Katzenellenbogen BS 2015 Dual suppression of estrogenic and inflammatory activities for targeting of endometriosis. Science Translational Medicine 7 271 ra279. (doi:10.1126/scitranslmed.3010626)

Zito G, Luppi S, Giolo E, Martinelli M, Venturin I, Di Lorenzo G \& Ricci G 2014 Medical treatments for endometriosis-associated pelvic pain. BioMed Research International 2014191967. (doi:10.1155/2014/191967)

Zondervan $K$, Weeks $D$, Colman $R$, Cardon $L$, Hadfield $R$, Schleffler J, Goudy Trainor A, Coe C, Kemnitz J \& Kennedy S 2004 Familial aggregation of endometriosis in a large pedigree of rhesus macaques. Human Reproduction 19 448-455. (doi:10.1093/humrep/ deh052)

Zorbas KA, Economopoulos KP \& Vlahos NF 2015 Continuous versus cyclic oral contraceptives for the treatment of endometriosis: a systematic review. Archives of Gynecology and Obstetrics 292 37-43. (doi:10.1007/s00404-015-3641-1)

Received 30 January 2016

First decision 3 March 2016

Revised manuscript received 14 April 2016

Accepted 9 May 2016 